Garcia Bournissen Facundo (Orcid ID: 0000-0002-8732-247X)

Altcheh Jaime (Orcid ID: 0000-0001-8820-0549)

\title{
REVIEW OF PHARMACOLOGICAL OPTIONS FOR THE TREATMENT OF
}

\section{ChAGAS DISEASE}

Fernanda Lascano (1, 3), Facundo García Bournissen (2), Jaime Altcheh (corresponding author) (1,

3)

Corresponding Author: Jaime Altcheh, Phd MD

Phone: +5401149634122

Mail: jaltcheh@gmail.com

\section{Affiliation:}

1) Instituto Multidisciplinario de Investigaciones en Patologías Pediátricas (IMIPP), Consejo Nacional de Investigaciones Científicas y Técnicas (CONICET), Gobierno de la Ciudad de la Nación Argentina, Buenos Aires, Argentina

2) Division of Pediatric Clinical Pharmacology, Department of Pediatrics, Schulich School of Medicine \& Dentistry, University of Western Ontario, Canada

3) Servicio de Parasitología y Chagas, Hospital de Niños Ricardo Gutiérrez, Buenos Aires, Argentina

This article has been accepted for publication and undergone full peer review but has not been through the copyediting, typesetting, pagination and proofreading process which may lead to differences between this version and the Version of Record. Please cite this article as doi: $10.1111 / \mathrm{bcp} .14700$ 
KEYWORDS: chagas disease treatment, children, chagas disease drugs, pediatric clinical pharmacology, nifurtimox, benznidazole, Trypanosoma cruzi

Funding: The authors received no funding specifically for this project. Dr Facundo Garcia-

Bournissen is funded by the University of Western Ontario, Dr Jaime Altcheh is funded by Hospital de Niños Ricardo Gutierrez, Buenos Aires, Argentina, and Dr Fernanda Lascano is the recipient of a "doctorate" scholarship by CONICET, Buenos Aires, Argentina.

Conflicts of interest: Dr Facundo Garcia Bournissen has consulted for Chemo for projects not related to benznidazole, and has participated in nifurtimox clinical trials sponsored by Bayer.

Dr Jaime Altcheh has consulted for Bayer, and for Chemo. Dr Fernanda Lascano has no potential conflicts of interest to disclose. 


\section{ABSTRACT}

Introduction: Chagas disease $(C D)$ is a worldwide problem, with over 8 million people infected in both rural and urban areas. CD was first described over a century ago, but only two drugs are currently available for CD treatment, benznidazole (BZN) and nifurtimox (NF). Treating CD infected patients, especially children and women of reproductive age, is vital in order to prevent long term sequelae, such as heart and gastrointestinal dysfunction, but this aim is still far from being accomplished. Currently, the strongest data to support benefit-risk considerations come from trials in children. Finally, treatment response biomarkers need further development as serology is being questioned as the best method to assess treatment response.

Areas covered: This article is a narrative review on the pharmacology of drugs for CD, particularly BZN and NF. Data on drug biopharmaceutical characteristics, safety and efficacy of both drugs are summarized from a clinical perspective. Current data on alternative compounds under evaluation for $C D$ treatment, and new possible treatment response biomarkers are also discussed.

Conclusion: Early diagnosis and treatment of $C D$, especially in pediatric patients, is vital for an effective and safe use of the available drugs (i.e. BZN and NF). New biomarkers for CD are urgently needed for the diagnosis and evaluation of treatment efficacy, and to guide efforts from academia and pharmaceutical companies to accelerate the process of new drugs development. 


\section{INTRODUCTION}

Chagas disease (CD) is a zoonosis caused by infection with Trypanosoma cruzi, a protozoan parasite. Humans can acquire this infection by contact with insect vectors (hematophagous triatomine or Reduviidae bugs), by ingestion of contaminated food ${ }^{1}$, congenital transmission, blood transfusions or organ or tissue transplants from infected donors. In the past, CD was believed to exclusively affect rural populations in Latin America, but movement of people from rural to urban areas (as well as expanding screening strategies to urban dwellers), has revealed the infection as a worldwide problem ${ }^{2,3}$. Congenital transmission in particular has become an important route of infection and the main reason for acute CD in non-endemic countries, such as North America and Europe.

The World Health Organization (WHO) estimates that over 8 million people worldwide are infected with $T$ cruzi, and that an excess of 10,000 deaths occur every year due to $C D^{2}$. Underdiagnosis of $C D$ cases is suspected to be as high as $90 \%$, and even higher in cases of congenital $C D$ which is alarming considering that estimated $T$. cruzi prevalence among pregnant women ranges from $2 \%$ to $40 \%$ depending on geographical area ${ }^{4,5}$.

CD has a clinical course characterized by an acute phase, commonly asymptomatic, that resolves spontaneously in most cases but which can sometimes (i.e. less than $5 \%$ of cases) be severe, leading to serious sequelae and even death. Following the acute phase, a chronic stage ensues, with patients usually remaining asymptomatic for many decades. However, approximately $30 \%$ of infected patients eventually develop progressive and irreversible target organ damage, mainly in the heart and/or esophagus and colon. The 'silent' asymptomatic phase between acute and chronic phases is referred to as 'indeterminate stage' by some authors. ${ }^{6,7}$

The decision to implement $C D$ treatment was historically based on age, due to limited evidence of efficacy, and an increasing frequency and severity of side effects in relation to patient age. ${ }^{8}$ Currently there is agreement in international clinical guidelines that anti-parasitic treatment 
is effective and therefore should be offered at least to 1) patients with acute $C D, 2$ ) all children with congenital or acquired acute CD 3) immunosuppressed hosts with acute or reactivation of chronic disease 4) women of childbearing age in order to prevent congenital transmissions ${ }^{9-12}$.

Treatment effectiveness in chronic CD continues to be highly debated ${ }^{13-15}$; for adults over 50 years old, trypanocidal therapy is still considered optional due to an unclear risk-benefit balance. On the one hand there is a general agreement that parasitic persistence increases the risk for development or progression of cardiac lesions in chronically infected patients and therefore parasite eradication may be necessary in the early stages of the disease ${ }^{16,17}$. On the other hand, advanced CD seems to involve irreversible cardiac damage, and therefore parasiticidal treatment of affected older patients may be futile ${ }^{13}$. However, the evidence for either position is still limited ${ }^{18}$

Unfortunately, anti-parasitic therapy has not been widely implemented, even for those age groups that can clearly benefit from it (e.g. pediatric patients, early chronic infections, etc.) in spite of existing national and international guidelines that support treatment. This failure to treat may possibly be explained by many obstacles, including health care providers' low awareness of $\mathrm{CD}$ and its treatment options, overblown concerns about side effects, low access to healthcare for many patients with $C D$, lack of an optimal straightforward test of $C D$ cure, widespread drug shortages and irregular supplies, and regulatory barriers ${ }^{19}$. Even though WHO 2020 Goals for CD included access to treatment and/or care of all infected/ill patients, and The London Declaration on Neglected Tropical Diseases ${ }^{20}$ announced plans for the elimination or control of Chagas disease by 2020 , current estimates indicate that less than $1 \%$ of CD infected patients are treated and those lofty aims are far away from becoming a reality. ${ }^{21}$ Sub-optimal CD treatment implementation continues in many countries in spite the fact that failing to treat a CD patient could be considered medical negligence in many jurisdictions ${ }^{22}$.

In South America, CD causes the loss of over 750,000 working days because of premature deaths and $\$ 1.2$ billion in productivity loss every year ${ }^{23}$. The calculated annual global burden of 
disease is over $\$ 600$ million dollars per year in health-care costs and $10 \%$ of this burden affects non-endemic countries ${ }^{24}$. According to a study conducted in Mexico that evaluated the impact and economic outcomes (costs, cost-effectiveness, cost-benefit) of identifying and treating different percentages of $C D$ patients in the acute and indeterminate phases, identifying and treating $C D$ cases earlier was always economically dominant compared to no treatment ${ }^{21}$. Authorities in charge of health policies should acknowledge that this would result not only in reduced transmission rates and better health outcomes but also in huge cost-savings, besides being a medical duty, and human rights issue.

Despite the fact that $C D$ was first described over a century $a^{25}{ }^{25}$, only two drugs are currently available for treatment, benznidazole (BZN) and nifurtimox (NF), which were developed over 40 years ago. Both drugs require prolonged treatments (30 to 60 days) and are associated with adverse events that increase in severity and prevalence with age. Prompt diagnosis and treatment, especially in pediatric patients, are vital for an effective use of these medications.

\section{Pharmacological tReatment OF CD}

Both NF and BZN are nitroheteroerocyclic drugs developed over four decades ago by Bayer and Roche, respectively. Their mechanism of action is believed to rely on intracellular activation, that generates intermediates affecting the parasite's vital biological functions ${ }^{26,27}$. Both drugs are highly liposoluble, with very low water solubility. The parasite`s mechanisms against these drugs relies on detoxifying molecules such as trypanothione ${ }^{28}$ a vital part of the free radical scavenging cycle that is recycled by the enzyme trypanothione disulfide reductase.

Treatment with BZN and NF is contraindicated during pregnancy in most guidelines, due to limited evidence on safety, yet there is evidence of low concentration of BZN or NF in breastmilk with no risk to infants during lactation ${ }^{29-31}$. 
These drugs are usually not recommended in patients with renal or hepatic impairment, mostly on the basis of lack of safety data. However, given that these drugs are almost completely metabolized, renal elimination only plays a marginal role in their clearance and use in kidney failure would be possible with appropriate monitoring for adverse events. Similarly, in cases requiring emergency treatment (e.g. CD meningoencephalitis), hepatic impairment should not be an obstacle for treatment assuming that strict monitoring can be implemented ${ }^{32}$.

Although BZN is more commonly used than NF, both drugs seem to have similar efficacy and safety profiles. Reported treatment responses in the chronic indeterminate phase in children (mostly based on measuring serologic titers) are near $90 \%$ after NF treatment ${ }^{33}$ and $94 \%$ for BNZ ${ }^{34,35}$. In adults NF has treatment response rate of 7-8\% ${ }^{36,37}$ and BZN between 2 and $40 \%{ }^{13,38}$, with more studies carried for BZN than NF in this area (see table 1). There are no current data formally comparing both drugs, but some clinical studies are currently ongoing attempting to address this issue, such as TESEO (NCT03981523) ${ }^{39}$.

Unfortunately, given the natural history of $C D$ and heterogeneity of response follow-up techniques, it is logistically challenging to treat this disease during the earlier asymptomatic chronic phase and follow that patient cohort to determine clinical outcomes, which can take decades to appear, with sufficient statistical power to differentiate potential effects in treated versus control patients. About 30 years ago two controlled placebo clinical trials assessed the efficacy of treatment in CD chronic phase in pediatric patients with good results ${ }^{35,40}$, and other studies followed those, leaving no doubt that the earlier children are treated, the better the response achieved ${ }^{8,40,41}$. Women in fertile age should also be treated to prevent congenital CD transmission ${ }^{9,40-42}$.

Unlike treatment for children or women of reproductive age, controversies regarding treatment of adult patients still abound; in 2016 the first prospective multi-centric and randomized $C D$ cohort study in older adults with advanced $C D$, the 'Benznidazole Evaluation for Interrupting Trypanosomiasis' (BENEFIT), was published, describing the outcomes of 2854 
patients with established Chagas heart disease that received BZN or placebo and were followed for 5.4 years $^{13}$. This study concluded that no significant morbidity or mortality reduction was achieved with anti-parasitic treatment in patients with advanced cardiac stage. On the other side, the evidence from cohort and historical controlled trials has supported treating most chronic patients at early stages, with the available drugs ${ }^{16,43-47}$.

Monitoring treatment is recommended for either drug, with complete blood counts, hepatic, and renal function testing. Frequency varies through different guidelines between every two and five weeks, always with a pre-treatment laboratory evaluation to compare later findings $s^{34,48}$.

\section{BENZNIDAZOLE}

\section{Brief Recent History}

Benznidazole (N- phenylmethyl-2-nitro-1H-imidazole-1-acetamide; CAS Number 22994-850) is the most commonly used drug for treatment of CD. It was developed by Roche (Ro 07-1051) $)^{49}$ and there have been three producers of BZN so far: Roche, Lafepe (public pharmaceutical company of Brazil), and Chemo (formerly Elea, an Argentine pharmaceutical company). Roche manufactured and distributed the drug (as Radanil@ or Rochagan(C) from 1967 until the early 2000s, when production was discontinued due to economic reasons ${ }^{49}$. Later, encouraged by pressure from scientific and medical organizations, Roche eventually transferred BZN production technology and remaining stocks to Lafepe, which committed to re-establish supply. Lafepe developed a pediatric formulation for children weighing $<20 \mathrm{~kg}$ (12.5 mg tablet) that was tested in clinical pediatric study in Argentina (sponsored by Drugs for Neglected Diseases initiative) ${ }^{8}$ and this formulation was registered in Brazil in 2011 and was included on the WHO's Essential Medicines List for children in 2013. 
BNZ was the first drug approved by the United States Food and Drug Administration (FDA) in 2017 for children ages two to twelve years with $C D^{50,51}$ and in April 2018, a pediatric formulation of BZN was approved in Argentina to treat children under the age of 2 years. BZN is also prescribed off-label for adolescents, adults, and children under 2 in countries where the drug has not been registered specifically for these age groups.

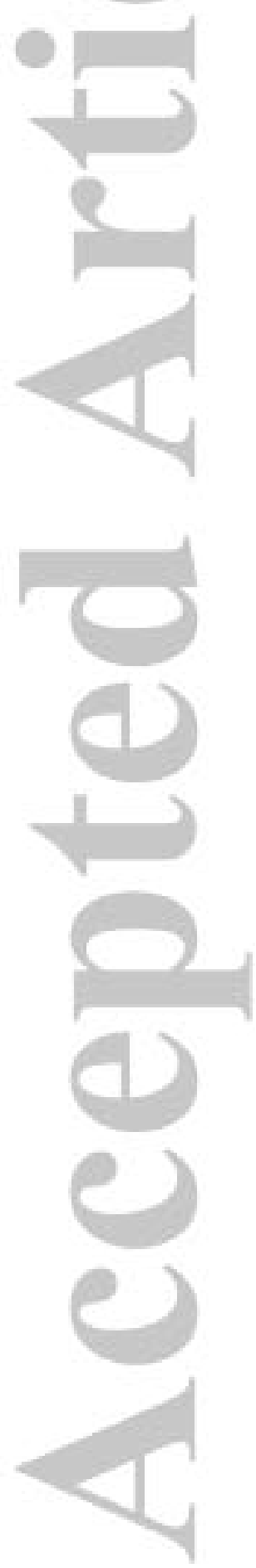




\section{BNZ Pharmacology}

Benznidazole is an oral, broad spectrum nitroimidazole antimicrobial that has activity against bacteria and several parasites. It has demonstrated efficacy against in vitro $T$. cruzi strains in several in vivo animal models ${ }^{52-56}$. According to the Biopharmaceutical Classification System $(\mathrm{BCS})^{57,58}$ BNZ belongs to Class IV drugs (reduced solubility and permeability); it is a liposoluble drug with very low solubility in water, and a weak base at physiological pH range. BNZ solubility in distilled water or simulated gastric and enteric fluids is reported between $0.2 \mathrm{mg} / \mathrm{ml}$ and 0.4 $\mathrm{mg} / \mathrm{ml}$. According to this, BZN is classified as a low-permeability drug with a log P of $1.64^{58}$.

BZN is considered a prodrug, requiring activation by parasite nitroreductase enzymes that

reduce $B Z N$, initiating a cascade of reactions leading to the formation of highly reactive drug metabolites ${ }^{27}$. The main parasite enzyme involved in BZN activation is believed to be a type 1 nitroreductase. The resulting BZN metabolites, such as dialdehyde glyoxal, bind to parasite macromolecules disrupting $T$. cruzi metabolism and other vital functions, and leading to parasite cell death ${ }^{27}$. However, using a metabolomics approach to asses BZN mechanism of action, Trochine et al. proposed that the covalent binding of BZN with low molecular weight thiols as well as with protein thiols is a primary cause of the drug's toxicity against $T$. cruzi, instead of glyoxal generation as formerly stated ${ }^{59}$. This suggests that BZN acts in a complex manner and there are still some remaining uncertainties about its mechanisms of action: metabolomic studies are a promising frontier in this research area.

$T$ cruzi resistance to BZN is not well described in literature. Some in-vitro studies have reported that some parasite strains have a 'natural' in-vitro resistance to BZN associated with overexpression of $A B C G$ transporter ${ }^{60}$, but this evidence has been questioned, as in-vitro results do not correlate with therapeutic outcomes in humans ${ }^{61}$. Other studies with in vitro data suggest that susceptibility of different T.cruzi strains to BZN fluctuates, but the $50 \%$ inhibitory concentration (IC50) values remain $\leq 19.5 \mu \mathrm{g} / \mathrm{mL}(75 \mu \mathrm{M})$ and can vary 10 -fold within the same 
assay. Activity against different forms of the parasite (epimastigotes, trypomastigotes, or amastigotes) also appears to vary within a relatively small range ${ }^{62,63}$, and it should be considered that many studies are performed on the epimastigote stage, which is easier to culture but not the human stage of the parasite. Additionally, time-kill studies indicate that BZN trypanocidal effect is both time and concentration dependent ${ }^{62-64}$. Using multiple T.cruzi strains and a high-throughput screening platform, a rapid trypanocidal effect was demonstrated with $100 \%$ parasite clearance against multiple divergent $T$. cruzi genotypes, a rate superior to that for ergosterol biosynthesis inhibitors ${ }^{63}$.

After oral administration, BZN is quickly absorbed from the human intestine (Ka $=1.14 / \mathrm{h})$, with a plasmatic peak within 2-4 hours after drug intake ${ }^{8,65}$. The impact of food on absorption has not been systematically investigated. Some evidence points to first step elimination by hepatic biotransformation and entero-hepatic recirculation, possibly with some degree of enteric metabolism as well, but little research has been conducted in this area. Absolute bioavailability in humans has never been formally estimated due to the absence of an intravenous formulation apt for human use, though a mean relative oral bioavailability of $91.7 \%$ in three healthy adults when comparing liquid to solid oral formulations was reported ${ }^{66}$. Steady-state plasma concentrations are reached within 3 days of initiation of a twice-daily dosing regimen ${ }^{8,66}$. BZN distributes widely into tissues, including the central nervous system $(\mathrm{CNS})^{67,68}$, with higher volume of distribution in children compared to adults ${ }^{8}$. The drug reaches CNS concentrations close to $70 \%$ of those observed in plasma, which has allowed successful treatment of Chagas CNS infections (e.g. meningoencephalitis) in immunosuppressed patients ${ }^{69-72}$. Plasma protein binding of BZN is approximately $50 \%$ and is thus not expected to lead to significant interactions with other drugs ${ }^{54}$. Clearance of BZN is mainly by biotransformation $(>80 \%)^{68,73}$, believed to take place mostly in the liver, probably by members of the cytochrome P450 (CYP) family and/or tissue nitroreductases. However, few studies to date have explored the details of the metabolic pathways responsible for BZN elimination. Approximately $6-20 \%$ of the drug can be found unchanged in 
urine, with differences depending on age of the patient (e.g., children seem to eliminate more unchanged drug in urine compared to adults); and the rest of the drug has been observed as reduced and conjugated. ${ }^{74}$

Mean BZN half-life is 13 hours in adults ${ }^{66}$ and significantly shorter in children ( 3 to 6 hours for 2 to 7 year-old patients and 9 to 10 hours in children 7 to 12 years) as observed in two prospective clinical trials ${ }^{8}$. This difference in clearance and half-life between different age groups implies average steady-state concentrations of BZN lower in children than in adults. Interestingly, this difference does not seem to affect the efficacy of BNZ since in a prospective clinical trial, all treated children showed good response to treatment despite lower plasma concentrations of the $\operatorname{drug}^{8}$. When comparing the data obtained in this study with previously reported adult results ${ }^{66}, \mathrm{a}$ progressive decrease in the clearance rate of BZN with increasing age was observed (i.e. the older the patient, the slower the drug was eliminated). The specific mechanisms for drug elimination in children and adults remain undiscovered. Research in the area is actively testing different hypotheses such as slower drug metabolism in adults and impaired drug absorption in younger children. BNZ pharmacokinetics and treatment response in teenagers and young adults have never been studied, so the assumption that it would be in between children and adults is so far unsupported by actual evidence.

The most commonly used BNZ dosing regimen, reported in the majority of the evidence published to date (see table 1 ) uses doses ranging from 5 to $8 \mathrm{mg} / \mathrm{kg} /$ day orally, in two daily doses for 30 to 60 days. BZN can also be administered in three daily doses, with a clear tendency in international guides for recommending 5 rather than $8 \mathrm{mg} / \mathrm{kg} /$ day and twice daily rather than thrice. ${ }^{48}$

Duration of treatment in children and adults is currently under review and some expert guides are already recommending shorter treatments ${ }^{8,75}$, supported by the fact that treatment in children is proven to be effective despite differences in PK with adults leading to lower concentrations and shorter half-lives, without detectable drop in effectiveness and with less 
adverse reactions ${ }^{8,75}$. A few trials enrolling children who received 30 days of treatment have showed good results ${ }^{42,76}$, and recent evidence points towards possible efficacy of lower BNZ doses or less frequent dosing for adults and teenagers to $0^{65,77,78}$. Lower treatment duration has also proven to be effective in adults in preliminary results of an unpublished clinical trial (NCT03378661) that showed $89.3 \%$ of therapeutic response (measured as a negative PCR) after a 4 week treatment compared to $82.8 \%$ after 8 week-treatment. There are currently other ongoing trials addressing BZN daily doses and duration as well such as BETTY trial ${ }^{79}$ and MULTIBENZ (NCT03191162), that may change treatment regimen in the next few years, assuming that sustained long term responses are demonstrated.

The most commonly observed adverse drug reactions (ADRs) associated with BZN use include rash and pruritus, headache, myalgia, and gastrointestinal discomfort. Skin reactions characteristically appear between 7 to 12 days after the start of treatment. Drug-associated hepatitis, leucopenia, peripheral neuropathy, and severe drug hypersensitivity (Stevens-Johnson syndrome and other reactions with systemic symptoms) have also been reported but less frequently. The median proportion of severe side effects is $2.7 \% .{ }^{45}$ Trough BZN serum concentrations did not appear to be related to the appearance of serious ADRs in a small study in adults $^{80}$, but evidence for a concentration-adverse event relationship has been observed in pediatric studies ${ }^{8,34}$. A recent prospective study in 99 participants reported some previously unreported ADRs; ten subjects presented psychiatric symptoms (anxiety, panic attacks, emotional lability and persecutory delusions), four patients reported sexual alterations (erectile dysfunction or delay in menstrual cycle with no alternative explanations) and one patient had a bronchospasm. The results of this study were in other aspects similar to previously published literature about BZN adverse reactions.$^{81}$ The safety profile of BZN in children is well described in the literature; data are consistent and do not suggest any signals of clinical concern ${ }^{8,34}$.

The incidence of ADRs between children and adults has not been compared directly (i.e. in a study enrolling both age groups), but ADRs seem rare and almost universally mild in younger 
children, and appear to increase gradually after 7 years of age in both frequency and severity. It is very infrequent to observe ADRs in newborns and children under 1 year old, and rates of treatment discontinuation due to ADRs are significantly low in children $34,47,76,82-85$ while these ranges between 11 and $45 \%$ in adult studies ${ }^{16,45,82,86}$.

The underlying biological mechanisms for the observed ADRs have not been studied in depth, but the immune system seems to play an important role, particularly in the case of cutaneous rashes and hypersensitivity reactions. This assumption is based on the timing for the moderate cutaneous reactions (7-12 days after onset of treatment) that mimics the time course of similar reactions associated to other unrelated medications known to cause rash (e.g. lamotrigine), and the observation of rare severe adverse reactions such as Stevens-Johnson syndrome and drug reactions with eosinophilia and systemic symptoms ${ }^{83,84}$. A common immunological trigger for these reactions and possibly a pharmacogenetic predisposition could explain these similarities, but studies of potential pharmacogenomic markers are missing. Some authors had formerly proposed to associate BZN with thioctic acid in order to prevent ADRs, based on this compound to increase hepatic elimination of BZN, but this has proven not to be effective when evaluated in-vivo. ${ }^{87}$

BZN has never been formally studied during pregnancy, but it is not recommended for pregnant women due to the lack of safety data; there is insufficient information about reproductive safety of this drug, other than the fact that there have been no reports of malformations or any other pregnancy complications. However, it should be considered that it is likely that an unknown number of women were exposed to BZN in the first trimester by accident and the lack of reports on safety data might be a good sign so far. Also, there are some reports of treatment during late-stage pregnancy in emergency situations that did not result in any complications for the baby and may have saved the mother's life ${ }^{69}$. The main recommendation therefore remains to avoid BZN during the first trimester of pregnancy and throughout pregnancy whenever possible until further information becomes available, though in case of an emergency or 
a life-threatening situation caused by $C D$, we recommend not delaying treatment because of an unproven teratogenic risk ${ }^{69}$.

BNZ has been classically contraindicated during lactation, but recent prospective studies and pharmacokinetic evaluations suggest that the risk of exposure to BZN from breastmilk for a breastfed baby is negligible, and lactation should not be considered a contraindication for CD treatment in those circumstances when treatment cannot be postponed. ${ }^{29}$

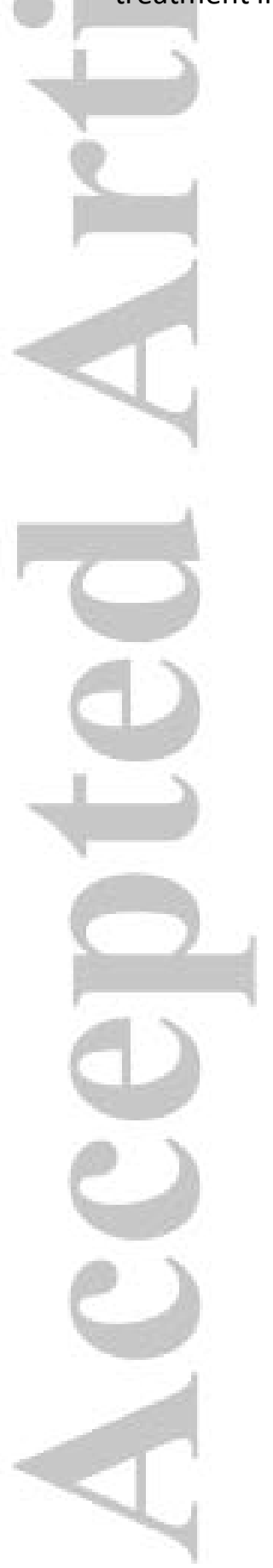




\section{NIFURTIMOX}

\section{Brief Recent History}

NF was manufactured in the 1970 s by Bayer -as Lampit ${ }^{\oplus}$ - but its development started earlier, in the 1960s as Bayer-2502. Similar to what happened with BZN, Bayer discontinued production in the 1990s due to low demand and almost null profitability, but reconsidered and restarted production later. Since then, country-level access to the drug has depended on individual states' agreements and negotiations with WHO and Bayer, and local bureaucratic and political decisions. Availability currently seems erratic in many South American countries, but it is expected to improve in the near future, after a clinical trial performed in children -CHICO study (NCT02625974) - that supported FDA approval of NF formulations for CD in the pediatric population.

\section{Nifurtimox Clinical Pharmacology}

Many aspects of NF clinical pharmacology are similar to those of BZN. There is also considerable lack of knowledge on many aspects of its PK, effectiveness, and metabolism. However, NF is currently undergoing extensive redevelopment, with some clinical trials already completed and others in process (NCT04274101) (see table 1).

NF mechanism of action is believed to be the generation of nitro-anion radicals, after activation by parasite nitroreductases in the presence of oxygen. This leads to production of free radicals that damage vital $T$. cruzi cell components, block DNA synthesis and accelerate DNA and RNA degradation 88,89 . 
Similarly to BZN, NF is hydrophobic, highly liposoluble and distributes widely to tissues, including the central nervous system ${ }^{90}$, a useful property for the treatment of T. cruzi CNS infections. It has a rapid absorption from gut (Ka $0.77 / \mathrm{h}$ ), but undergoes extensive first-pass elimination (much higher than BZN), leading to only a small fraction of orally administered NF reaching systemic circulation ${ }^{91,92}$. NF is administered orally and reaches peak plasma concentrations after 2 to 4 hours ${ }^{32,90,93}$ with a relatively short half-life (approximately 3 hours in adults, and similar in children based on very limited data) $)^{94,95}$. Liver elimination accounts for virtually all NF clearance (i.e., unchanged NF elimination in urine is less than $1 \%$ of the administered dose)..$^{96}$

According to a recent trial that reported biopharmaceutical characteristics after oral administration of $30 \mathrm{mg}$ and $120 \mathrm{mg}$ tablets ${ }^{96}$, total systemic exposure to NF was approximately $71 \%$ greater after food than in a fasted state. Mean (\%CV) NF AUC estimates ranged between 1676-2670 $\mathrm{gg} \cdot \mathrm{h} / \mathrm{L}(19-32 \%)$ and Cmax estimates ranged between 425-568 $\mathrm{\mu g} / \mathrm{L}$ (26-50\%) following administration of single dose $120 \mathrm{mg} \mathrm{NF}$ with food in adult CD patients. The median time to reach maximum concentration (Tmax) of NF under fed conditions was 4 hours (range: 2 to 8 hours). Interestingly, in this study Cmax increased 68\%, AUC increased $71 \%$, and Tmax increased by 1 hour after a high-fat meal compared to fasted conditions. ${ }^{96}$

Animal liver experiments of NF metabolism have suggested a number of metabolites ${ }^{97}$, but this aspect has only been studied in a limited number of humans, with preliminary confirmation of the metabolites observed in animal experiments and further observation of a range of minor metabolites ${ }^{98}$. Data from animal studies also suggests that CYP enzymes are responsible for NF metabolism, but no human data is publicly available identifying specific CYP isoforms, or associated enzymes, responsible for biotransformation ${ }^{98,99}$. NF plasma protein binding is approximately $50 \%$ and not expected to play a significant role in drug-drug interactions ${ }^{100}$. This drug is a substrate for the ABCG2 transporter, commonly known as Breast Cancer Resistance 
Protein (BCRP), which has been shown to influence NF transport across the blood-brain barrier, as well as its excretion into breastmilk ${ }^{30,31,101}$.

NF apparent volume of distribution is high $(\mathrm{V} / \mathrm{F}=760 \mathrm{~L})$, suggesting both an extensive distribution into tissues and also a significant pre-systemic elimination (i.e., a limited bioavailability), such as that observed in animal studies ${ }^{91}$.

Neither NF optimal dose nor the optimal treatment duration for CD is well defined. Initially, treatments tended to be long (90-120 days $)^{102}$ but were subsequently reduced to mimic BZN treatment spans (approximately 60 days) ${ }^{103,104}$. The recent trial CHICO study (NCT02625974) studied alternative dosing (30 versus 60 days) observing similar serological and parasitological treatment responses for children under 2 years; but in order to apply these conclusions to all pediatric patients, long term follow-up would be crucial. Commonly used dose ranges from 8 to 15 $\mathrm{mg} / \mathrm{kg} /$ day divided in three daily administrations, but optimal daily dose frequency has never been duly studied either, and was defined only on the basis of NF half-life.

The most commonly observed ADRs are anorexia and weight loss, irritability, sleepiness, and other nervous system signs and symptoms ${ }^{83,103,105}$. NF use is also associated with rash, pruritus, and drug-associated hepatitis but less frequently than BZN. Depression, peripheral neuropathy, and psychiatric symptoms have also been reported, less commonly. Similar to BZN, NF-associated ADRs seem much more common and severe in adults and are usually mild in children, including neonates ${ }^{96,106,107}$. Notably, there is some evidence that suggests that patients who develop a severe drug reaction to BZN may still be treated safely with NF ${ }^{108}$.

Similar to BZN, NF is considered contraindicated during pregnancy and lactation: virtually no data is available on the safety of this drug during the first trimester of pregnancy, and therefore it is still advisable to avoid its use at this stage. About lactation, recently published and ongoing studies on NF transfer into breastmilk strongly suggest that the drug is safe during breastfeeding, and treatment of a lactating mother should not be discouraged if needed ${ }^{30,31}$. 


\section{ASSESSMENT OF TREATMENT EFFICACY: EXISTING BIOMARKERS OF TREATMENT}

\section{RESPONSE AND NEW ADVANCES}

The appropriate markers of $C D$ cure (i.e. a patient being free from $C D$ and not at risk of developing target organ involvement such as cardiomyopathy, cardiac failure, mega-esophagus or mega-colon, etc.) have been subject to intense debate for decades, in part due to prolonged persistence of T.cruzi specific antibodies, lack of sensitivity of parasitological tests, and need for long-term follow-up (generally years or decades) to observe negative seroconversion of conventional serological tests, as well as a general lack of understanding of the parasite biology in the human and the kinetics of drug response. Serology (and, in particular, negative seroconversion) has been heralded for many years as the gold standard for treatment response, largely guided by the successful results observed after treating acute infections or early chronic infections in children ${ }^{8,109}$ (see table 1). However, treatment of older patients, or even children over 7 years of age, does not lead to negative seroconversion for decades (if ever) ${ }^{8,40,42,109}$, even if a drop in antibody titers is observed early after pharmacological treatment. This fact is easy to understand, if one considers that persistent immune system stimulation (e.g. as would be the case in chronic CD due to persistent antigen shedding by deep-tissue $T$ cruzi nests) is bound to generate immune responses that would last for a long time even after complete parasite clearance by NF or BZN.

Negative seroconversion continues to be the (somehow arbitrarily) chosen method to ascertain a treatment response, both in general practice and research. Reported serologic response rates are as high as $96 \%$ for congenitally infected infants ${ }^{8,109-111}, 76 \%$ for acute infections ${ }^{112}, 63 \%{ }^{40,113}$ to $90 \%{ }^{113}$ for chronically infected children, and $37 \%$ for chronically infected adults ${ }^{114}$. These rates have marked variability among different published studies due to different 
serologic techniques employed, with sometimes poorly evaluated, different sensitivities and specificities, used to determine treatment response as the primary outcome of clinical trials ${ }^{115,116}$. It would be reasonable to consider that more sensitive serological techniques would under-estimate time and rates of cure (i.e. would yield positive antibody results with lower titers), with no correlation with clinical outcomes such as organ impact, but this still requires more research to confirm. In order to study the correlation between serologic response and organ damage, a recent study of a pediatric cohort performed a median after treatment follow-up of 10 years of treated children with electrocardiograms (ECG), 24 hours ECG (Holter) and Speckletracking strain echocardiography and observed no $C D$ untoward impact on heart function in this population years after treatment, supporting the low correlation between serological tests and clinical response ${ }^{117}$. Also, T. cruzi detection tests currently in use in some countries for long term follow up of patients such as polymerase chain reaction against T.cruzi-DNA (PCR) or different serology techniques, were initially developed for diagnostic purposes. Furthermore, many of the methods used have been repeatedly changed across the years, and comparison of results from recent clinical studies to older studies involves a degree of uncertainty even if comparing tests that are nominally the same (e.g. RT-PCR done in recent years would have used primers and protocols very different to those used 10 years ago) ${ }^{41,46}$. In this context, new markers of cure are needed. Alternative early markers of cure have been suggested, such as decrease of total anti-T.cruzi antibody titers (i.e. instead of negative seroconversion) or use of non-conventional serological techniques ${ }^{118,119}$ such as specific lytic anti- $\alpha$-Gal antibodies known as anti-F2/3 antibodies ${ }^{120}$. Other CD biomarkers suggested by scientific literature so far have been reviewed by different authors too, but the general impression is that they all still require more research, and validation. Table 2 summarizes the biomarkers studied. ${ }^{46,121,122}$

PCR has been proposed as a sensitive and specific method to detect T.cruzi parasitemia in newborns ${ }^{41,123,124}$ and has also shown good results for the assessment of treatment failure, as a persistently positive result after treatment clearly is evidence of failure to eliminate the 
parasite ${ }^{125}$. However, while PCR may be more sensitive than current methods in some cases, the lack of standardization of the method across centers is a still unresolved issue. Furthermore, actual rate of false positives is still under debate, and may vary among testing laboratories (and different techniques used). Other issues such as cost and instrument availability and technical skills, conspire to limit the use of this method at the moment, but considering its good results so far and its feasibility of being easily applied in clinical settings, the investment in improving PCR methodologies is worthwhile. The CD community must focus on suitable strategies for parasite DNA extraction in lower sample volumes, the equivalence between blood and tissue parasitemia; the reduction of false negatives, as well as the validation and standardization of PCR assays; and the equivalence of PCR readouts with negative seroconversion. ${ }^{109,126-128}$

Considering all available evidence, we could conclude that despite the need of trials in this area, a negative PCR -associated to a persistent decrease of T.cruzi antibodies titers- should be the chosen criteria used to assess treatment response and to follow-up after treatment in our time. 


\section{Pharmacological Treatment: NeW treatment strategies and}

\section{ALTERNATIVE DRUGS}

As mentioned before, there are few recent advances in BZN and NF pharmacology, which is disappointing considering their longevity. Some improvements in drug formulation have been proposed (e.g. application of nanotechnologies such as nanocrystals, polymeric nanoparticles, and lipid nanostructures) as an attractive approach to improve solubility and dissolution of BNZ and NFX, hopefully leading to dose reductions and, perhaps, novel treatment schemes, but virtually no clinical research has been undertaken with this proposed formulations ${ }^{129,130}$.

New potentially effective drugs have been proposed on the basis multiple targets in the parasite cell. Ergosterol biosynthesis enzymes in particular have been well studied, and CYP51 (sterol 14-Demethylase) was proposed as an interesting target, both due to its importance in parasite survival, and the availability of multiple medications already in the market (i.e. azole antifungal drugs) that could be easily repositioned for clinical trials in CD 104,131-134. This repositioning approach is advantageous in view of the cost and time-consuming process required compared to the development of new medicines, especially in neglected diseases, since repositioned drugs already have their toxicological and pharmacokinetic profile assessed when used on their previous therapeutic target ${ }^{135}$. Unfortunately, only allopurinol and a few azoles have been studied in clinical trials, observational studies, and case reports - there is an ongoing randomized double-blind, placebo controlled trial being carried (NCT03193749) comparing Amiodarone hydrochloride with placebo but there are no preliminary results disclosed so far. Despite allopurinol has shown to be useful in combination with NF or Benznidazole in small trials, evidence is still insufficient ${ }^{136-138}$. From azoles, posaconazole was compared in high and low doses versus placebo and research results concluded it has an acceptable antitrypanosomal activity, but also a significant increase in treatment failure compared with BZN group ${ }^{139}$. Another randomized 
placebo-controlled trial in adults tested E1224 (a ravuconazole pro-drug in different dosing regimens) and BZN versus placebo, and found that E1224 + BZN group displayed a transient, suppressive effect on parasite clearance, whereas BZN showed early and sustained efficacy until 12 months of follow-up. This transitory effect was shown only in high dose sub-group while parasite levels in the low-dose and short-dose E1224 groups gradually returned to placebo levels 140. In summary, from azole`s research, some former promising repositionable drugs such as monotherapy with ketoconazole, ravuconazole or posaconazole has not proven to be efficacious for the treatment of chronic T. cruzi infection ${ }^{139-141}$ and the combination of posaconazole and BZN did not provide any further efficacy or safety advantages over BZN monotherapy ${ }^{142,143}$.

Similarly, pre-clinical studies have identified interesting targets for drug action including cruzipain (parasite lysosomal cysteine), B citocrome, trypanothione reductase system, cyclophilins, $\mathrm{N}$-myristoylome, carbonic anhydrases and NMDA glutamate receptor. ${ }^{143,144}$ However, none of these targets have drugs in clinical trials yet, and the ever-mounting costs of drug development and human clinical trials make it difficult to believe that many new molecules for CD would be coming into the market in the foreseeable future.

Fexinidazole is a drug previously repositioned for Trypanosoma brucei gambiense infection (African trypanosomiasis) after demonstrating effectiveness in a randomized controlled trial ${ }^{145}$. Also, fexinidazole's safety and pharmacokinetics had been properly studied in humans, proving that oral administration is safe and well tolerated ${ }^{132,133,146}$. Considering this drug is effective in clearing T.cruzi as well in pre-clinical studies, an ongoing randomized, double-blind, placebo controlled trial is being carried out in Argentina, Bolivia and Spain to assess its efficacy in CD (NCT02498782).

Interestingly, some natural compounds and dietary supplements such as microalgae extracts $^{147}$, wasp venom ${ }^{148}$, coumarins ${ }^{149}$, South American Vernonieae ${ }^{150}$, curcumin ${ }^{151}$ and Resveratrol $^{152}$ have been also studied for anti-tripanosomal activity, but more research is required 
to draw conclusions, and there is still close to no human clinical data. The use of natural compounds to treat known diseases might lead to effective benefit-cost resources, considering that many of these compounds are not subject to patent restrictions and may be widely available. However, formal clinical testing should be performed before any of these compounds is used in patients. ${ }^{104}$

In spite of a relative abundance of preclinical molecular candidates and potential repositionable drugs, there are currently no new classes of drugs in the clinical development pipeline for $C D$ and $B Z N$ and NF remain the only two available drugs for treatment with relatively solid clinical data to support their use.

\section{Conclusion}

$C D$ is a highly neglected tropical disease that has become an increasing worldwide problem in last decades. There is an alarming number of undiagnosed and untreated patients, and an urgent need for researchers and providers to change this fact. The choice for treatment remains between two drugs, created a century ago. The strongest data to support benefit-risk considerations come from trials in children (see Table 1).

Scientific and economic effort should be urgently aimed to supply early diagnose and treatment in this population, in addition to more research in this area. New biomarkers for $C D$ are strongly needed for the diagnosis and detection of treatment efficacy and efforts from academia and pharmaceutical companies to accelerate the process of new drugs development are necessary. Also, an extra effort to standardize a predictive Chagas disease in vivo model should be done and validated in order to improve its predictability and to ease its comparison and reproducibility.

Early diagnosis and treatment of Chagas diseases, especially in pediatric patients, are vital for an effective and safe use of the available drugs (BZN and NF) medications. 


\section{References}

1. Filigheddu MT, Górgolas M, Ramos JM. Enfermedad de Chagas de transmisión oral. Med Clin (Barc). 2017;148(3):125-131. doi:10.1016/j.medcli.2016.10.038

2. WHO | Epidemiology. WHO.

3. Coura JR, Viñas PA, Junqueira ACV. Ecoepidemiology, Short history and control of chagas disease in the endemic countries and the new challenge for non-endemic countries. Mem Inst Oswaldo Cruz. 2014;109(7):856-862. doi:10.1590/0074-0276140236

4. Martins-Melo FR, da Silveira Lima M, Ramos AN, Alencar CH, Heukelbach J. Systematic review: Prevalence of Chagas disease in pregnant women and congenital transmission of Trypanosoma cruzi in Brazil: A systematic review and meta-analysis. Trop Med Int Heal. 2014;19(8):943-957. doi:10.1111/tmi.12328

5. Basile L, Ciruela P, Requena-Méndez A, et al. Epidemiology of congenital Chagas disease 6 years after implementation of a public health surveillance system, Catalonia, 2010 to 2015. Eurosurveillance. 2019;24(26). doi:10.2807/1560-7917.ES.2019.24.26.19-00011

6. Coura JR, de Abreu LL, Pereira JB, Willcox HP. Morbidade da doenĉa de Chagas. IV. Estudo longitudinal de dez anos emPains e Iguatama, Minas Gerais, Brasil. Mem Inst Oswaldo Cruz. 1985;80(1):73-80. doi:10.1590/s0074-02761985000100011

7. Pérez-Molina JA, Molina I. Chagas disease. Lancet. 2018;391(10115):82-94. doi:10.1016/S0140-6736(17)31612-4

8. Altcheh J, Moscatelli G, Mastrantonio G, et al. Population Pharmacokinetic Study of Benznidazole in Pediatric Chagas Disease Suggests Efficacy despite Lower Plasma Concentrations than in Adults. PLoS Negl Trop Dis. 2014;8(5).

doi:10.1371/journal.pntd.0002907

9. Moscatelli G, Moroni S, García-Bournissen F, et al. Prevention of congenital chagas through treatment of girls and women of childbearing age. Mem Inst Oswaldo Cruz. 2015;110(4):507-509. doi:10.1590/0074-02760140347

10. Sosa-Estani S, Colantonio L, Segura EL. Therapy of chagas disease: implications for levels of prevention. J Trop Med. 2012;2012:292138. doi:10.1155/2012/292138

11. Paho, Who. Guidelines for the diagnosis and treatment of Chagas disease. 2019. 
www.paho.org/permissions. Accessed May 29, 2020.

12. Laucella SA, Mazliah DP, Bertocchi G, et al. Changes in Trypanosoma cruzi -Specific Immune Responses after Treatment: Surrogate Markers of Treatment Efficacy . Clin Infect Dis. 2009;49(11):1675-1684. doi:10.1086/648072

13. Morillo CA, Marin-Neto JA, Avezum A, et al. Randomized trial of benznidazole for chronic chagas' cardiomyopathy. N Engl J Med. 2015;373(14):1295-1306. doi:10.1056/NEJMoa1507574

14. Issa VS, Bocchi EA. Antitrypanosomal agents: Treatment or threat? Lancet. 2010;376(9743):768. doi:10.1016/S0140-6736(10)61372-4

15. Bern C, Martin DL, Gilman RH. Acute and Congenital Chagas Disease. In: Advances in Parasitology. Vol 75. Academic Press; 2011:19-47. doi:10.1016/B978-0-12-385863-4.000022

16. Viotti R, Vigliano C, Lococo B, et al. Long-term cardiac outcomes of treating chronic chagas disease with benznidazole versus no treatment: A nonrandomized trial. Ann Intern Med. 2006;144(10):724-734. doi:10.7326/0003-4819-144-10-200605160-00006

17. Echeverría LE, Rojas LZ, Rueda-Ochoa OL, et al. Circulating Trypanosoma Cruzi Load and Major Cardiovascular Outcomes in Patients with Chronic Chagas Cardiomyopathy: A Prospective Cohort Study. Trop Med Int Heal. 2020;(Accepted Author Manuscript). doi:10.1111/TMI.13487

18. Rassi A, Marin-Neto JA, Rassi A. Chronic chagas cardiomyopathy: A review of the main pathogenic mechanisms and the efficacy of aetiological treatment following the BENznidazole evaluation for interrupting trypanosomiasis (BENEFIT) trial. Mem Inst Oswaldo Cruz. 2017;112(3):224-235. doi:10.1590/0074-02760160334

19. Müller Kratz J, Garcia Bournissen F, Forsyth CJ, Sosa-Estani S. Clinical and pharmacological profile of benznidazole for treatment of Chagas disease. Expert Rev Clin Pharmacol. 2018;11(10):943-957. doi:10.1080/17512433.2018.1509704

20. London Declaration on Neglected Tropical Diseases. https://www.who.int/neglected_diseases/London_Declaration_NTDs.pdf. Accessed September 11, 2020.

21. Bartsch SM, Avelis CM, Asti L, et al. The economic value of identifying and treating Chagas 
disease patients earlier and the impact on Trypanosoma cruzi transmission. Angheben A, ed. PLoS NegI Trop Dis. 2018;12(11):1-24. doi:10.1371/journal.pntd.0006809

22. Altcheh J. La enfermedad de Chagas a 100 años de su descubrimiento. Arch Argent Pediatr. 2010;108(1):4-5.

23. Conteh L, Engels T, Molyneux DH. Socioeconomic aspects of neglected tropical diseases. Lancet. 2010;375(9710):239-247. doi:10.1016/S0140-6736(09)61422-7

24. Lee BY, Bacon KM, Bottazzi ME, Hotez PJ. Global economic burden of Chagas disease: A computational simulation model. Lancet Infect Dis. 2013;13(4):342-348. doi:10.1016/S1473-3099(13)70002-1

25. Chagas C. Nova tripanozomiaze humana: estudos sobre a morfolojia e o ciclo evolutivo do Schizotrypanum cruzi n. gen., n. sp., ajente etiolojico de nova entidade morbida do homem. Mem Inst Oswaldo Cruz. 1909;1(2):159-218. doi:10.1590/s0074-02761909000200008

26. Hall BS, Bot C, Wilkinson SR. Nifurtimox activation by trypanosomal type I nitroreductases generates cytotoxic nitrile metabolites. J Biol Chem. 2011;286(15):13088-13095. doi:10.1074/jbc.M111.230847

27. Hall BS, Wilkinson SR. Activation of benznidazole by trypanosomal type I nitroreductases results in glyoxal formation. Antimicrob Agents Chemother. 2012;56(1):115-123. doi:10.1128/AAC.05135-11

28. Vázquez K, Paulino M, Salas CO, Zarate-Ramos JJ, Vera B, Rivera G. Trypanothione Reductase: A Target for the Development of Anti- Trypanosoma cruzi Drugs. Mini-Reviews Med Chem. 2017;17(11):939-946. doi:10.2174/1389557517666170315145410

29. García-Bournissen F, Moroni S, Marson ME, et al. Limited infant exposure to benznidazole through breast milk during maternal treatment for Chagas disease. Arch Dis Child. 2015;100(1):90-94. doi:10.1136/archdischild-2014-306358

30. Moroni S, Marson ME, Moscatelli G, et al. Negligible exposure to nifurtimox through breast milk during maternal treatment for Chagas Disease. PLoS Negl Trop Dis. 2019;13(8):1-10. doi:10.1371/journal.pntd.0007647

31. Garcia-Bournissen F, Altcheh J, Panchaud A, Ito S. Is use of nifurtimox for the treatment of Chagas disease compatible with breast feeding? A population pharmacokinetics analysis. Arch Dis Child. 2010;95(3):224-228. doi:10.1136/adc.2008.157297 
32. Vasquez I, Paredes J, Gonzalez Martin G, Thambo S PC. The pharmacokinetics of nifurtimox in chronic renal failure. Eur J Clin Pharmacol. 1992;42(6):671-3. doi:10.1007/BF00265935

33. Streiger ML, del Barco ML, Fabbro DL, Arias ED, Amicone NA, Mirtha Streiger Paraje El Pozo DL. Estudo longitudinal e quimioterapia específica em crianças, com doença de Chagas crônica, residentes em área de baixa endemicidade da República Argentina Longitudinal study and specific chemotherapy in children with chronic Chagas' disease, residing in a. Rev Soc Bras Med Trop. 2004;37(5):365-375. doi:https://doi.org/10.1590/S003786822004000500001

34. Altcheh J, Moscatelli G, Moroni S, Garcia-Bournissen F, Freilij H. Adverse events after the use of benznidazole in infants and children with Chagas disease. Pediatrics. 2011;127(1):e212-e218. doi:10.1542/peds.2010-1172

35. Sgambatti De Andrade ALS, Zicker F, De Oliveira RM, et al. Randomised trial of efficacy of benznidazole in treatment of early Trypanosoma cruzi infection. Lancet. 1996;348(9039):1407-1413. doi:10.1016/S0140-6736(96)04128-1

36. Coura JR, De Castro SL. A critical review on chagas disease chemotherapy. Mem Inst Oswaldo Cruz. 2002;97(1):3-24. doi:10.1590/S0074-02762002000100001

37. Lauria-Pires L, Braga MS, Vexenat AC, et al. Progressive chronic chagas heart disease ten years after treatment with anti-Trypanosoma cruzi nitroderivatives. Am J Trop Med Hyg. 2000;63(3-4):111-118. doi:10.4269/ajtmh.2000.63.111

38. Fernández ML, Marson ME, Ramirez JC, et al. Pharmacokinetic and pharmacodynamic responses in adult patients with chagas disease treated with a new formulation of benznidazole. Mem Inst Oswaldo Cruz. 2016;111(3):218-221. doi:10.1590/007402760150401

39. Villar JC, Herrera VM, Pérez Carreño JG, et al. Nifurtimox versus benznidazole or placebo for asymptomatic Trypanosoma cruzi infection (Equivalence of Usual Interventions for Trypanosomiasis - EQUITY): Study protocol for a randomised controlled trial. Trials. 2019;20(1). doi:10.1186/s13063-019-3423-3

40. Sosa Estani S, Segura EL, Ruiz AM, Velazquez E, Porcel BM, Yampotis C. Efficacy of chemotherapy with benznidazole in children in the indeterminate phase of Chagas' disease. Am J Trop Med Hyg. 1998;59(4):526-529. doi:10.4269/ajtmh.1998.59.526 
41. Schijman AG, Altcheh J, Burgos JM, et al. Aetiological treatment of congenital Chagas' disease diagnosed and monitored by the polymerase chain reaction. J Antimicrob Chemother. 2003;52(3):441-449. doi:10.1093/jac/dkg338

42. Chippaux JP, Clavijo ANS, Santalla JA, Postigo JR, Schneider D, Brutus L. Antibody drop in newborns congenitally infected by Trypanosoma cruzi treated with benznidazole. Trop Med Int Heal. 2010;15(1):87-93. doi:10.1111/j.1365-3156.2009.02431.x

43. Marson ME, Altcheh J, Moscatelli G, Moroni S, García-Bournissen F, Mastrantonio GE. Identification of N-Benzylacetamide as a Major Component of Human Plasmatic Metabolic Profiling of Benznidazole. Vol 40. Springer-Verlag France; 2015:209-217. doi:10.1007/s13318-014-0195-8

44. Vallejo A, Monge-Maillo B, Gutiérrez C, Norman FF, López-Vélez R, Pérez-Molina JA. Changes in the immune response after treatment with benznidazole versus no treatment in patients with chronic indeterminate Chagas disease. Acta Trop. 2016;164:117-124. doi:10.1016/j.actatropica.2016.09.010

45. Villar JC, Perez JG, Cortes OL, et al. Trypanocidal drugs for chronic asymptomatic Trypanosoma cruzi infection. Cochrane Database Syst Rev. 2014;2014(5). doi:10.1002/14651858.CD003463.pub2

46. Pinazo MJ, Thomas MC, Bua J, et al. Biological markers for evaluating therapeutic efficacy in Chagas disease, a systematic review. Expert Rev Anti Infect Ther. 2014;12(4):479-496. doi:10.1586/14787210.2014.899150

47. Albareda MC, Natale MA, De Rissio AM, et al. Distinct treatment outcomes of antiparasitic therapy in trypanosoma cruzi-infected children is associated with early changes in Cytokines, Chemokines, and T-Cell Phenotypes. Front Immunol. 2018;9:1-15. doi:10.3389/fimmu.2018.01958

48. Olivera MJ, Fory JA, Olivera AJ. Therapeutic drug monitoring of benznidazole and nifurtimox: A systematic review and quality assessment of published clinical practice guidelines. Rev Soc Bras Med Trop. 2017;50(6):748-755. doi:10.1590/0037-8682-0399-2016

49. Jannin J, Villa L. An overview of Chagas disease treatment. In: Memorias Do Instituto Oswaldo Cruz. Vol 102. ; 2007:95-97. doi:10.1590/s0074-02762007005000106

50. Pinheiro E, Brum-Soares L, Reis R, Cubides JC. Chagas disease: Review of needs, neglect, 
and obstacles to treatment access in Latin America. Rev Soc Bras Med Trop.

2017;50(3):296-300. doi:10.1590/0037-8682-0433-2016

51. Alpern JD, Lopez-Velez R, Stauffer WM. Access to benznidazole for Chagas disease in the United States-Cautious optimism? PLoS Neg/ Trop Dis. 2017;11(9):e0005794. doi:10.1371/journal.pntd.0005794

52. Francisco $A F$, Jayawardhana $\mathrm{S}$, Lewis $\mathrm{MD}$, et al. Nitroheterocyclic drugs cure experimental Trypanosoma cruzi infections more effectively in the chronic stage than in the acute stage. Sci Rep. 2016;6(1):35351. doi:10.1038/srep35351

53. Chatelain E. Chagas disease drug discovery: Toward a new era. J Biomol Screen. 2015;20(1):22-35. doi:10.1177/1087057114550585

54. Richle RW, Raaflaub J. Difference of effective antitrypanosomal dosages of benznidazole in mice and man. Chemotherapeutic and pharmacokinetic results. Acta Trop. 1980;37(3):257261. http://www.ncbi.nlm.nih.gov/pubmed/6106364.

55. Romanha AJ, de Castro SL, Soeiro M de NC, et al. In vitro and in vivo experimental models for drug screening and development for Chagas disease. Mem Inst Oswaldo Cruz. 2010;105(2):233-238. doi:10.1590/S0074-02762010000200022

56. Chatelain E, loset JR. Phenotypic screening approaches for Chagas disease drug discovery. Expert Opin Drug Discov. 2018;13(2):141-153. doi:10.1080/17460441.2018.1417380

57. The Biopharmaceutics Classification System (BCS) Guidance | FDA.

https://www.fda.gov/about-fda/center-drug-evaluation-and-researchcder/biopharmaceutics-classification-system-bcs-guidance. Accessed September 10, 2020.

58. del Moral Sanchez JM, Gonzalez-Alvarez I, Cerda-Revert A, et al. Biopharmaceutical optimization in neglected diseases for paediatric patients by applying the provisional paediatric biopharmaceutical classification system. Br J Clin Pharmacol. 2018;84(10):22312241. doi:10.1111/bcp.13650

59. Trochine A, Creek DJ, Faral-Tello P, Barrett MP, Robello C. Benznidazole Biotransformation and Multiple Targets in Trypanosoma cruzi Revealed by Metabolomics. Pollastri MP, ed. PLoS NegI Trop Dis. 2014;8(5):e2844. doi:10.1371/journal.pntd.0002844

60. Zingales B, Araujo RGA, Moreno M, et al. A novel ABCG-like transporter of Trypanosoma cruzi is involved in natural resistance to benznidazole. Mem Inst Oswaldo Cruz. 
2015;110(3):433-444. doi:10.1590/0074-02760140407

61. Moreno M, D'ávila DA, Silva MN, et al. Trypanosoma cruzi benznidazole susceptibility in vitro does not predict the therapeutic outcome of human Chagas disease. Mem Inst Oswaldo Cruz. 2010;105(7):918-924. doi:10.1590/\$0074-02762010000700014

62. Canavaci AMC, Bustamante JM, Padilla AM, et al. In Vitro and In Vivo High-throughput assays for the testing of Anti-trypanosoma cruzi compounds. Geary TG, ed. PLoS Negl Trop Dis. 2010;4(7):e740. doi:10.1371/journal.pntd.0000740

63. Moraes CB, Giardini MA, Kim H, et al. Nitroheterocyclic compounds are more efficacious than CYP51 inhibitors against Trypanosoma cruzi: Implications for Chagas disease drug discovery and development. Sci Rep. 2014;4(1):1-11. doi:10.1038/srep04703

64. Polak A, Richle R. Mode of action of the 2-nitroimidazole derivative benznidazole. Ann Trop Med Parasitol. 1978;72(1):45-54. doi:10.1080/00034983.1978.11719278

65. Molina I, Salvador F, Sánchez-Montalvá A, et al. Pharmacokinetics of benznidazole in healthy volunteers and implications in future clinical trials. Antimicrob Agents Chemother. 2017;61(4):139-144. doi:10.1128/AAC.01912-16

66. Raaflaub J. Multiple-dose kinetics of the trypanosomicide benznidazole in man. Arzneimittelforschung. 1980;30(12):2192-2194. http://www.ncbi.nlm.nih.gov/pubmed/6783051.

67. Roberts JT, Bleehen NM. Benznidazole with CCNU: A clinical phase i toxicity study. Int J Radiat Oncol Biol Phys. 1985;11(2):331-334. doi:10.1016/0360-3016(85)90155-5

68. Workman P, White RA, Walton MI, Owen LN, Twentyman PR. Preclinical pharmacokinetics of benznidazole. Br J Cancer. 1984;50(3):291-303. doi:10.1038/bjc.1984.176

69. Bisio M, Altcheh J, Lattner J, et al. Benznidazole treatment of chagasic encephalitis in pregnant woman with AIDS. Emerg Infect Dis. 2013;19(9):1490-1492. doi:10.3201/eid1909.130667

70. Cordova E, Boschi A, Ambrosioni J, Cudos C, Corti M. Reactivation of Chagas disease with central nervous system involvement in HIV-infected patients in Argentina, 1992-2007. Int J Infect Dis. 2008;12(6):587-592. doi:10.1016/j.ijid.2007.12.007

71. Cohen V, Ceballos V, Rodríguez N, et al. Chagas' disease as a cause of cerebral mass in a 
patient with lymphoblastic leukemia in remission. Arch Argent Pediatr. 2010;108(6). doi:10.1590/S0325-00752010000600016

72. Montero M, Mir M, Sulleiro E, et al. High-dose benznidazole in a 62-year-old Bolivian kidney transplant recipient with Chagas central nervous system involvement. Int J Infect Dis. 2019;78:103-106. doi:10.1016/j.ijid.2018.10.014

73. Walton MI, Workman P. Nitroimidazole bioreductive metabolism. Quantitation and characterisation of mouse tissue benznidazole nitroreductases in vivo and in vitro. Biochem Pharmacol. 1987;36(6):887-896. doi:10.1016/0006-2952(87)90181-X

74. Rocco D, Perez Montilla C, Moroni S, Altcheh J G-BF. F Benznidazole metabolites in urine from patients treated for Chagas disease Abstract. Meet Am Soc Clin Pharmacol. 2018.

75. Ministerio de Salud y Desarrollo Social de la Republica Argentina. Atención Del Paciente Infectado Con Trypanosoma Cruzi, Guia Para El Equipo de Salud, $3^{\circ}$ Edición-2018.

76. Viotti R, Alarcón De Noya B, Araujo-Jorge T, et al. Towards a paradigm shift in the treatment of chronic chagas disease. Antimicrob Agents Chemother. 2014;58(2):635-639. doi:10.1128/AAC.01662-13

77. Álvarez MG, Hernández Y, Bertocchi G, et al. New scheme of intermittent benznidazole administration in patients chronically infected with Trypanosoma cruzi: A pilot short-term follow-up study with adult patients. Antimicrob Agents Chemother. 2016;60(2):833-837. doi:10.1128/AAC.00745-15

78. Soy $D$, Aldasoro E, Guerrero L, et al. Population pharmacokinetics of benznidazole in adult patients with Chagas disease. Antimicrob Agents Chemother. 2015;59(6):3342-3349. doi:10.1128/AAC.05018-14

79. Cafferata ML, Toscani MA, Althabe F, et al. Short-course Benznidazole treatment to reduce Trypanosoma cruzi parasitic load in women of reproductive age (BETTY): a non-inferiority randomized controlled trial study protocol. Reprod Health. 2020;17(1):128. doi:10.1186/s12978-020-00972-1

80. Pinazo MJ, Guerrero L, Posada E, Rodríguez E, Soy D, Gascon J. Benznidazole-related adverse drug reactions and their relationship to serum drug concentrations in patients with chronic chagas disease. Antimicrob Agents Chemother. 2013;57(1):390-395. doi:10.1128/AAC.01401-12 
81. Aldasoro E, Posada E, Requena-Méndez A, et al. What to expect and when: Benznidazole toxicity in chronic Chagas' disease treatment. J Antimicrob Chemother. 2018;73(4):10601067. doi:10.1093/jac/dkx516

82. Viotti R, Vigliano C, Lococo B, et al. Side effects of benznidazole as treatment in chronic Chagas disease: Fears and realities. Expert Rev Anti Infect Ther. 2009;7(2):157-163. doi:10.1586/14787210.7.2.157

83. Yun O, Lima MA, Ellman T, et al. Feasibility, drug safety, and effectiveness of etiological treatment programs for Chagas disease in Honduras, Guatemala, and Bolivia: 10-Year experience of Médecins Sans Frontières. Gürtler RE, ed. PLoS Negl Trop Dis. 2009;3(7):e488. doi:10.1371/journal.pntd.0000488

84. Sperandio da Silva GM, Mediano MFF, Hasslocher-Moreno AM, et al. Benznidazole treatment safety: the Médecins Sans Frontières experience in a large cohort of Bolivian patients with Chagas' disease. J Antimicrob Chemother. 2017;72(9):2596-2601. doi:10.1093/jac/dkx180

85. Bertocchi GL, Vigliano CA, Lococo BG, Petti MA, Viotti RJ. Clinical characteristics and outcome of 107 adult patients with chronic Chagas disease and parasitological cure criteria. Trans R Soc Trop Med Hyg. 2013;107(6):372-376. doi:10.1093/TRSTMH/TRT029

86. de Pontes V, de Souza Júnior A, da Cruz F, Coelho H, Dias A, Coêlho I, de Fátima O. Adverse reactions in Chagas disease patients treated with benznidazole, in the State of Ceara. Rev Soc Bras Med Trop. 2010;43(2):182-187. doi:S0037-86822010000200015

87. Sosa-Estani S, Armenti A, Araujo G, Viotti R, Araujo G, Lococo B, Ruiz Vera B, Vigliano C, de Rissio AM S EL. Treatment of Chagas Disease With Benznidazole and Thioctic Acid. Medicina (B Aires). 2004;64(1).

88. Bartel LC, Montalto De Mecca M, Rodríguez De Castro C, Bietto FM, Castro JA. Metabolization of nifurtimox and benznidazole in cellular fractions of rat mammary tissue. Hum Exp Toxicol. 2010;29(10):813-822. doi:10.1177/0960327110361756

89. Docampo R, Moreno SNJ, Stoppani AOM. Nitrofuran enhancement of microsomal electron transport, superoxide anion production and lipid peroxidation. Arch Biochem Biophys. 1981;207(2):316-324. doi:10.1016/0003-9861(81)90039-4

90. Arancibia A, Gonzalez Martin G, Paulos C, Paredes J,Vasquez I , Thambo S. Pharmacokinetics 
of a nitrofuran compound, nifurtimox, in healthy volunteers. Int I Clin Pharmacol Ther Toxicol. 1989;27(9):454-457.

91. Patzschke K, Wegner LA, Duhm B, Maul W MH. Investigations on the pharmacokinetics of nifurtimox- $35 \mathrm{~S}$ in the rat and dog. Arzneimittelforschung. 1972;22(9):1617-1624. https://www.ncbi.nlm.nih.gov/pubmed/4630484.

92. Kuemmerle A, Schmid C, Kande V, et al. Prescription of concomitant medications in patients treated with Nifurtimox Eflornithine Combination Therapy (NECT) for T.b. gambiense second stage sleeping sickness in the Democratic Republic of the Congo. PLoS Negl Trop Dis. 2020;14(1):e0008028. doi:10.1371/journal.pntd.0008028

93. Paulos, C. Paredes, J. Vasquez I, Kunze, G. González-Martin G. High-performance liquid chromatographic determination of nifurtimox in human serum. J Chromatogr B Biomed Sci Appl. 1988;433(C):359-362. doi:10.1016/S0378-4347(00)80621-0

94. Saulnier Sholler GL, Bergendahl GM, Brard L, et al. A phase 1 study of nifurtimox in patients with relapsed/refractory neuroblastoma. J Pediatr Hematol Oncol. 2011;33(1):25-30. doi:10.1097/MPH.0b013e3181f47061

95. Raether W, Hänel H. Nitroheterocyclic drugs with broad spectrum activity. Parasitol Res. 2003;90(S1):S19-S39. doi:10.1007/s00436-002-0754-9

96. Heino Strass, Ethel Feleder, Facundo Garcia-Bournisen, Johannes Nagelschmitz, Boris Weimann, Gustavo Yerino JA. Biopharmaceutical characteristics of nifurtimox tablets for age and bodyweight adjusted dosing in patients with Chagas disease. Clin Pharmacol Drug Dev. 2020. doi:10.1002/cpdd.871

97. Gonzalez-Martin G, Paulos C, Guevara A PG. Disposition of nifurtimox and metabolite activity against Trypanosoma cruzi using rat isolated perfused liver. J Pharm Pharmacol. 1994;46(5):356-359. doi:10.1111/j.2042-7158.1994.tb03812.x

98. Pérez Montilla C, Moroni S, González N, Moscatelli G, Altcheh J, García Bournissen F. P38 Identification of Nifurtimox metabolites in urine of pediatric Chagas disease patients by UHPLC-MS/MS. Arch Dis Child. 2019;104(6):e32.3-e33. doi:10.1136/archdischild-2019esdppp.76

99. Letelier ME, Izquierdo P, Godoy L, Lepe AM, Faúndez M. Liver microsomal biotransformation of nitro-aryl drugs: Mechanism for potential oxidative stress induction. $J$ 
Appl Toxicol. 2004;24(6):519-525. doi:10.1002/jat.999

100. Masana M, de Toranzo EG CJ. Studies on nifurtimox nitroreductase activity in liver and other rat tissues. Arch Int Pharmacodyn Ther. 1984:270.

https://www.ncbi.nlm.nih.gov/pubmed/6497502.

101. Watson CP, Dogruel M, Mihoreanu L, et al. The transport of nifurtimox, an antitrypanosomal drug, in an in vitro model of the human blood-brain barrier: Evidence for involvement of breast cancer resistance protein. Brain Res. 2012;1436:111-121. doi:10.1016/j.brainres.2011.11.053

102. Cancado J, Salgado A, Marra D, Alvares J MJ. [Clinical therapeutic trial in chronic Chagas' disease using nifurtimox in 3 schedules of long duration]. Ensaio terapeutico cl'inico na doenca de Chagas cronica com o nifurtimox em tres esquemas de dura coa prolongada. Rev Inst Med Trop Sao Paulo. Rev Inst Med Trop Sao Paulo. 1975;17(2):111-127.

103. Jackson Y, Alirol E, Getaz L, Wolff H, Combescure C, Chappuis F. Tolerance and Safety of Nifurtimox in Patients with Chronic Chagas Disease. Clin Infect Dis. 2010;51(10):e69-e75. doi:10.1086/656917

104. Ribeiro V, Dias N, Paiva T, et al. Current trends in the pharmacological management of Chagas disease. Int J Parasitol Drugs Drug Resist. 2020;12:7-17. doi:10.1016/j.ijpddr.2019.11.004

105. Forsyth CJ, Hernandez S, Olmedo W, Abuhamidah A, Traina MI SD. Safety Profile of Nifurtimox for Treatment of Chagas Disease in the United States. Clin Infect Dis. 2016;63(8):1056-1062. doi:10.1093/cid/ciw477

106. Alarcón de Noya B, Ruiz-Guevara R, Noya O, et al. Long-term comparative pharmacovigilance of orally transmitted Chagas disease: first report. Expert Rev Anti Infect Ther. 2017;15(3):319-325. doi:10.1080/14787210.2017.1286979

107. Freilij, H., Altcheh J. Congenital Chagas' Disease: Diagnostic and Clinical Aspects. Clin Infect Dis. 1995;21(3). doi:10.1093/CLINIDS/21.3.551

108. Pérez-Molina JA, Sojo-Dorado J, Norman F, et al. Nifurtimox therapy for Chagas disease does not cause hypersensitivity reactions in patients with such previous adverse reactions during benznidazole treatment. Acta Trop. 2013;127(2):101-104. doi:10.1016/j.actatropica.2013.04.003 
109. Moscatelli G, Moroni S, Bournissen FG, et al. Longitudinal follow up of serological response in children treated for Chagas disease. Angheben A, ed. PLoS Negl Trop Dis. 2019;13(8):114. doi:10.1371/journal.pntd.0007668

110. Alonso-Vega C, Billot C, Torrico F. Achievements and Challenges upon the Implementation of a Program for National Control of Congenital Chagas in Bolivia: Results 2004-2009. PLoS Negl Trop Dis. 2013;7(7). doi:10.1371/journal.pntd.0002304

111. Garcia-Bournissen F, Altcheh J, Giglio N, Mastrantonio G, Omar Della Védova C, Koren G. Pediatric clinical pharmacology studies in Chagas disease: Focus on Argentina. In: Pediatric Drugs. Vol 11. ; 2009:33-37. doi:10.2165/0148581-200911010-00012

112. Cançado JR. Long term evaluation of etiological treatment of Chagas disease with benznidazole. Rev Inst Med Trop Sao Paulo. 2002;44(1):29-37. doi:10.1590/S003646652002000100006

113. Andrade ALSS, Martelli CMT, Oliveira RM, et al. Short report: Benznidazole efficacy among Trypanosoma cruzi-infected adolescents after a six-year follow-up. Am J Trop Med Hyg. 2004;71(5):594-597. doi:10.4269/ajtmh.2004.71.594

114. Fabbro DL, Streiger ML, Arias ED, Bizai ML, Del Barco M, Amicone NA. Trypanocide treatment among adults with chronic Chagas disease living in Santa Fe City (Argentina), over a mean follow-up of 21 years: Parasitological, serological and clinical evolution. Rev Soc Bras Med Trop. 2007;40(1):1-10. doi:10.1590/s0037-86822007000100001

115. Parrado R, Ramirez JC, de la Barra A, et al. Usefulness of serial blood sampling and PCR replicates for treatment monitoring of patients with chronic Chagas disease. Antimicrob Agents Chemother. 2019;63(2):e01191-18. doi:10.1128/AAC.01191-18

116. Alonso-Padilla J, Gallego M, Schijman AG, Gascon J. Molecular diagnostics for Chagas disease: up to date and novel methodologies. Expert Rev Mol Diagn. 2017;17(7):699-710. doi:10.1080/14737159.2017.1338566

117. Gonzalez NL, Moroni S, Moscatelli G, et al. Early antiparasitic treatment prevents progression of Chagas disease: Results of a long-term cardiological follow-up study in a pediatric population. medRxiv. July 2020:2020.06.30.20143370. doi:10.1101/2020.06.30.20143370

118. Viotti R, Vigliano C, Álvarez MG, et al. Impact of aetiological treatment on conventional and 
multiplex serology in chronic chagas disease. Costa Santiago H da, ed. PLoS Negl Trop Dis. 2011;5(9):e1314. doi:10.1371/journal.pntd.0001314

119. Fabbro D, Velazquez E, Bizai ML, et al. Avaliação do tratamento tripanossomicida em coorte de adultos chagásicos crônicos através de técnicas sorológicas convencionais e ELISA-F29. Rev Inst Med Trop Sao Paulo. 2013;55(3):167-172. doi:10.1590/\$0036-46652013000300005

120. Altcheh J, Corral R, Biancardi MA FH. Anti-F2/3 antibodies as cure marker in children with congenital Trypanosoma cruzi infection. Med (B Aires). 2003;63(1):37-40.

121. Pinho RT, Waghabi MC, Cardillo F, Mengel J, Antas PRZ. Scrutinizing the biomarkers for the neglected chagas disease: How remarkable! Front Immunol. 2016;7(AUG). doi:10.3389/fimmu.2016.00306

122. Requena-Méndez A, López MC, Angheben A, et al. Evaluating Chagas disease progression and cure through blood-derived biomarkers: a systematic review. Expert Rev Anti Infect Ther. 2013;11(9):957-976. doi:10.1586/14787210.2013.824718

123. Russomando G, De Tomassone MMC, De Guillen I, et al. Treatment of congenital Chagas disease diagnosed and followed up by the Polymerase Chain Reaction. Am J Trop Med Hyg. 1998;59(3):487-491. doi:10.4269/ajtmh.1998.59.487

124. Bianchi F, Cucunubá Z, Guhl F, et al. Follow-up of an Asymptomatic Chagas Disease Population of Children after Treatment with Nifurtimox (Lampit) in a Sylvatic Endemic Transmission Area of Colombia. 2015;9(2). doi:10.1371/ journal.pntd.0003465

125. Sguassero $Y$, Cuesta CB, Roberts KN, et al. Course of chronic Trypanosoma cruzi infection after treatment based on parasitological and serological tests: A systematic review of follow-up studies. PLoS One. 2015;10(10):1-23. doi:10.1371/journal.pone.0139363

126. Freilij, H., Altcheh J. Chagas Disease, A Clinical Approach. (Birkhäuser, ed.).; 2019.

127. Implementation Strategy of Bio-Molecular Techniques for Early Diagnose of Congenital Syphilis and Chagas Diseases. https://clinicaltrials.gov/ct2/show/NCT04084379.

128. Galvão L, Chiari E, Macedo AM, Luquetti A, Silva S, Andrade AL. PCR Assay for Monitoring Trypanosoma cruzi Parasitemia in Childhood after Specific Chemotherapy. J Clin Microbiol. 2003;41(11):5066-5070. doi:10.1128/JCM.41.11.5066-5070.2003

129. Brito TK, Silva Viana RL, Gonçalves Moreno CJ, et al. Synthesis of Silver Nanoparticle 
Employing Corn Cob Xylan as a Reducing Agent with Anti-Trypanosoma cruzi Activity. Int J Nanomedicine. 2020;15:965-979. doi:10.2147/IJN.S216386

130. Arrúa EC, Seremeta KP, Bedogni GR, Okulik NB, Salomon CJ. Nanocarriers for effective delivery of benznidazole and nifurtimox in the treatment of chagas disease: A review. Acta Trop. 2019;198(April):105080. doi:10.1016/j.actatropica.2019.105080

131. Scarim CB, Jornada DH, Chelucci RC, de Almeida L, dos Santos JL, Chung MC. Current advances in drug discovery for Chagas disease. Eur J Med Chem. 2018;155:824-838. doi:10.1016/j.ejmech.2018.06.040

132. Watson JA, Strub-Wourgraft N, Tarral A, Ribeiro I, Tarning J, White NJ. Pharmacokineticpharmacodynamic assessment of the hepatic and bone marrow toxicities of the new trypanoside fexinidazole. Antimicrob Agents Chemother. 2019;63(4). doi:10.1128/AAC.02515-18

133. Bahia MT, Nascimento AFS, Mazzeti AL, et al. Antitrypanosomal activity of fexinidazole metabolites, potential new drug candidates for Chagas disease. Antimicrob Agents Chemother. 2014;58(8):4362-4370. doi:10.1128/AAC.02754-13

134. Simões-Silva MR, De Araújo JS, Peres RB, et al. Repurposing strategies for Chagas disease therapy: The effect of imatinib and derivatives against Trypanosoma cruzi. Parasitology. 2019;146(8):1006-1012. doi:10.1017/S0031182019000234

135. Alberca LN, Sbaraglini ML, Balcazar D, et al. Discovery of novel polyamine analogs with antiprotozoal activity by computer guided drug repositioning. J Comput Aided Mol Des. 2016;30(4):305-321. doi:10.1007/s10822-016-9903-6

136. Mazzeti AL, Diniz L de F, Gonçalves KR, et al. Synergic effect of allopurinol in combination with nitroheterocyclic compounds against trypanosoma cruzi. Antimicrob Agents Chemother. 2019;63(6). doi:10.1128/AAC.02264-18

137. Perez-Mazliah DE, Alvarez MG, Cooley G, et al. Sequential combined treatment with allopurinol and benznidazole in the chronic phase of Trypanosoma cruzi infection: a pilot study. J Antimicrob Chemother. 2013;68(2):424-437. doi:10.1093/jac/dks390

138. Rassi A, Luquetti AO, Rassi A, et al. Specific treatment for Trypanosoma cruzi: lack of efficacy of allopurinol in the human chronic phase of Chagas disease. Am J Trop Med Hyg. 2007;76(1):58-61. http://www.ncbi.nlm.nih.gov/pubmed/17255230. 
139. Molina I, Gómez i Prat J, Salvador F, et al. Randomized Trial of Posaconazole and Benznidazole for Chronic Chagas' Disease. N Engl J Med. 2014;370(20):1899-1908. doi:10.1056/NEJMoa1313122

140. Torrico F, Gascon J, Ortiz L, et al. Treatment of adult chronic indeterminate Chagas disease with benznidazole and three E1224 dosing regimens: a proof-of-concept, randomised, placebo-controlled trial. Lancet Infect Dis. 2018;18(4):419-430. doi:10.1016/S14733099(17)30538-8

141. Brener Z, Cançado JR, Galvão LM, et al. An experimental and clinical assay with ketoconazole in the treatment of Chagas disease. Mem Inst Oswaldo Cruz. 88(1):149-153. doi:10.1590/s0074-02761993000100023

142. Morillo CA, Waskin H, Sosa-Estani S, et al. Benznidazole and Posaconazole in Eliminating Parasites in Asymptomatic T. Cruzi Carriers: The STOP-CHAGAS Trial. J Am Coll Cardiol. 2017;69(8):939-947. doi:10.1016/j.jacc.2016.12.023

143. Villalta F, Rachakonda G. Advances in preclinical approaches to Chagas disease drug discovery. Expert Opin Drug Discov. 2019;14(11):1161-1174. doi:10.1080/17460441.2019.1652593

144. Souza HFS, Rocha SC, Damasceno FS, et al. The effect of memantine, an antagonist of the NMDA glutamate receptor, in in vitro and in vivo infections by Trypanosoma cruzi. PLoS Negl Trop Dis. 2019;13(9). doi:10.1371/journal.pntd.0007226

145. Mesu VKBK, Kalonji WM, Bardonneau C, et al. Oral fexinidazole for late-stage African Trypanosoma brucei gambiense trypanosomiasis: a pivotal multicentre, randomised, noninferiority trial. Lancet. 2018;391(10116):144-154. doi:10.1016/S0140-6736(17)32758-7

146. Deeks ED. Fexinidazole: First Global Approval. Drugs. 2019;79(2):215-220. doi:10.1007/s40265-019-1051-6

147. Veas R, Rojas-Pirela M, Castillo C, et al. Microalgae extracts: Potential anti-Trypanosoma cruzi agents? Biomed Pharmacother. 2020;127. doi:10.1016/j.biopha.2020.110178

148. Albuquerque KF, Torres MDT, Lima DB, et al. Wasp venom peptide as a new antichagasic agent. Toxicon. 2020;181:71-78. doi:10.1016/j.toxicon.2020.04.099

149. Soares FGN, Goëthel G, Kagami LP, et al. Novel coumarins active against Trypanosoma cruzi and toxicity assessment using the animal model Caenorhabditis elegans. BMC Pharmacol 
Toxicol. 2019;20. doi:10.1186/s40360-019-0357-z

150. Sosa A, Salamanca Capusiri E, Amaya S, et al. Trypanocidal activity of South American Vernonieae (Asteraceae) extracts and its sesquiterpene lactones. Nat Prod Res. 2020. doi:10.1080/14786419.2020.1739682

151. Hernández M, Wicz S, Santamaría MH, Corral RS. Curcumin exerts anti-inflammatory and vasoprotective effects through amelioration of NFAT-dependent endothelin-1 production in mice with acute Chagas cardiomyopathy. Mem Inst Oswaldo Cruz. 2018;113(9):e180171. doi:10.1590/0074-02760180171

152. Vilar-Pereira G, Carneiro VC, Mata-Santos H, et al. Resveratrol Reverses Functional Chagas Heart Disease in Mice. Vieira LQ, ed. PLOS Pathog. 2016;12(10):e1005947. doi:10.1371/journal.ppat.1005947

153. Robello C, Maldonado DP, Hevia A, et al. The fecal, oral, and skin microbiota of children with Chagas disease treated with benznidazole. PLoS One. 2019;14(2):1-11. doi:10.1371/journal.pone.0212593

154. Monje Rumi M, Pérez Brandán C, Gil JF, et al. Benznidazole treatment in chronic children infected with Trypanosoma cruzi: Serological and molecular follow-up of patients and identification of Discrete Typing Units. Acta Trop. 2013;128(1):130-136. doi:10.1016/j.actatropica.2013.07.003

155. Chippaux, JP et al. Evaluation of Compliance to Congenital Chagas Disease Treatment: Results of a Randomised Trial in Bolivia. Trans R Soc Trop Med Hyg. 2013;107(1). doi:10.1093/TRSTMH/TRSO04

156. Escribà $J M$, Ponce $E$, Romero $A$ de $D$, et al. Treatment and seroconversion in a cohort of children suffering from recent chronic Chagas infection in Yoro, Honduras. Mem Inst Oswaldo Cruz. 2009;104(7):986-991. doi:10.1590/\$0074-02762009000700008

157. Flores-Chavez M, Bosseno MF, Bastrenta B, et al. Polymerase chain reaction detection and serologic follow-up after treatment with benznidazole in Bolivian children infected with a natural mixture of Trypanosoma cruzi I and II. Am J Trop Med Hyg. 2006;75(3):497-501. doi:10.4269/ajtmh.2006.75.497

158. Galvão LMC, Chiari E, Macedo AM, Luquetti AO, Silva SA, Andrade ALSS. PCR Assay for Monitoring Trypanosoma cruzi Parasitemia in Childhood after Specific Chemotherapy. J Clin 
Microbiol. 2003;41(11):5066-5070. doi:10.1128/JCM.41.11.5066-5070.2003

159. Schenone F H, Contreras L M, Solari I A, García C A, Rojas S A, Lorca H M. Nifurtimox treatment of chronic Chagasic infection in children (2). Rev Med Chil. 2003;131(9):10891090.

160. Solari A. Treatment of Trypanosoma cruzi-infected children with nifurtimox: a 3 year follow-up by PCR. J Antimicrob Chemother. 2001;48(4):515-519. doi:10.1093/jac/48.4.515

161. Solari A, Contreras MC, Lorca M, Garcia A, Salinas P, Ortiz S, Soto A, Arancibia C SH. Yield of Xenodiagnosis and PCR in the Evaluation of Specific Chemotherapy of Chagas' Disease in Children. Bol Chil Parasitol. 1998;53(1-2).

162. De Apparecida Levy AM, Boainain E KJ. In Situ Indirect Fluorescent Antibody: A New Specific Test to Detect Ongoing Chagasic Infections. J Clin Lab Anal. 1996;10(2). doi:10.1002/(sici)1098-2825(1996)10:2<98::aid-jcla7>3.0.co;2-h

163. Almeida IC, Covas DT, Soussumi LMT, Travassos LR. A highly sensitive and specific chemiluminescent enzyme-linked immunosorbent assay for diagnosis of active Trypanosoma cruzi infection. Transfusion. 1997;37(8):850-857. doi:10.1046/j.15372995.1997.37897424410.x

164. Pinazo M-J, Thomas M-C, Bustamante J, Correia De Almeida I, Lopez M-C, Gascon J. Biomarkers of therapeutic responses in chronic Chagas disease: state of the art and future perspectives. Mem Inst Oswaldo Cruz, Rio Janeiro. 2015;110(3):422-432. doi:10.1590/007402760140435

165. Negrette OS, Valdéz FJS, Lacunza CD, et al. Serological evaluation of specific-antibody levels in patients treated for chronic chagas' disease. Clin Vaccine Immunol. 2008;15(2):297-302. doi:10.1128/CVI.00106-07

166. Fabbro DL, Olivera V, Bizai ML, et al. Humoral immune response against $P 2 \beta$ from Trypanosoma cruzi in persons with chronic chagas disease: Its relationship with treatment against parasites and myocardial damage. Am J Trop Med Hyg. 2011;84(4):575-580. doi:10.4269/ajtmh.2011.10-0261

167. Fernández-Villegas A, Pinazo MJ, Marañón C, et al. Short-term follow-up of chagasic patients after benznidazole treatment using multiple serological markers. BMC Infect Dis. 2011;11. doi:10.1186/1471-2334-11-206 
168. Flechas ID, Cuellar A, Cucunubá ZM, et al. Characterising the KMP-11 and HSP-70 recombinant antigens' humoral immune response profile in chagasic patients. BMC Infect Dis. 2009;9(1):186. doi:10.1186/1471-2334-9-186

169. Krautz GM, Galvão LM, Cançado JR, Guevara-Espinoza A, Ouaissi A, Krettli AU. Use of a 24kilodalton Trypanosoma cruzi recombinant protein to monitor cure of human Chagas' disease. J Clin Microbiol. 1995;33(8):2086.

170. Krettli AU. The utility of anti-trypomastigote lytic antibodies for determining cure of Trypanosoma cruzi infections in treated patients: An overview and perspectives. Mem Inst Oswaldo Cruz. 2009;104(SUPPL. 1):142-151. doi:10.1590/S0074-02762009000900020

171. Cooley G, Etheridgel RD, Boehlke C, et al. High throughput selection of effective serodiagnostics for Trypanosoma cruzi infection. PLoS Negl Trop Dis. 2008;2(10). doi:10.1371/journal.pntd.0000316

172. Meira WSF, Galvão LMC, Gontijo ED, Machado-Coelho GLL, Norris KA, Chiari E. Use of the Trypanosoma cruzi Recombinant Complement Regulatory Protein To Evaluate Therapeutic Efficacy following Treatment of Chronic Chagasic Patients. J Clin Microbiol. 2004;42(2):707712. doi:10.1128/JCM.42.2.707-712.2004

173. Zrein M, Granjon E, Gueyffier L, et al. A novel antibody surrogate biomarker to monitor parasite persistence in Trypanosoma cruzi-infected patients. PLoS Negl Trop Dis. 2018;12(2). doi:10.1371/journal.pntd.0006226

174. Ndao M, Spithill TW, Caffrey R, et al. Identification of novel diagnostic serum biomarkers for chagas' disease in asymptomatic subjects by mass spectrometric profiling. $J$ Clin Microbiol. 2010;48(4):1139-1149. doi:10.1128/JCM.02207-09

175. Santamaria C, Chatelain E, Jackson Y, et al. Serum biomarkers predictive of cure in Chagas disease patients after nifurtimox treatment. BMC Infect Dis. 2014;14(1):1-12. doi:10.1186/1471-2334-14-302

176. Pinazo $\mathrm{M}$ et al. Hypercoagulability biomarkers in Trypanosoma cruzi-infected patients. Thromb Haemost. 2011;106(6):17-23.

177. Pinazo M-J, Posada E de J, Izquierdo L, et al. Altered Hypercoagulability Factors in Patients with Chronic Chagas Disease: Potential Biomarkers of Therapeutic Response. CorreaOliveira R, ed. PLoS NegI Trop Dis. 2016;10(1):e0004269. doi:10.1371/journal.pntd.0004269 
178. Laucella S, Segura EL, Riarte A, Sosa ES. Soluble platelet selectin (sP-selectin) and soluble vascular cell adhesion molecule-1 (sVCAM-1) decrease during therapy with benznidazole in children with indeterminate form of Chagas' disease. Clin Exp Immunol. 1999;118(3):423427. doi:10.1046/j.1365-2249.1999.01070.x

179. Dutra WO, Da Luz ZMP, Cançado JR, et al. Influence of parasite presence on the immunologic profile of peripheral blood mononuclear cells from chagasic patients after specific drug therapy. Parasite Immunol. 1996;18(11):579-585. doi:10.1046/j.13653024.1996.d01-29.x

180. Sathler-Avelar R, Vitelli-Avelar DM, Massara RL, et al. Benznidazole treatment during earlyindeterminate Chagas' disease shifted the cytokine expression by innate and adaptive immunity cells toward a type 1-modulated immune profile. Scand J Immunol. 2006;64(5):554-563. doi:10.1111/j.1365-3083.2006.01843.x

181. Argüello RJ, Albareda MC, Alvarez MG, et al. Inhibitory receptors are expressed by Trypanosoma cruzi-specific effector T cells and in hearts of subjects with chronic chagas disease. PLoS One. 2012;7(5). doi:10.1371/journal.pone.0035966 
Table 1: Summary of relevant trials of Benznidazole and/or Nifurtimox in children

\begin{tabular}{|c|c|c|c|c|c|c|}
\hline $\begin{array}{c}\text { Author/ } \\
\text { Reference }\end{array}$ & $\begin{array}{c}\text { Patient } \\
\text { Population }\end{array}$ & Study Design & Dosing Regimen & Patients & Therapeutic Effect & Safety \\
\hline $\begin{array}{l}\text { Moscatelli et } \\
\text { al } 2019109\end{array}$ & $\begin{array}{c}\text { IP* of } C D<20 \text { years } \\
\text { of age } \\
\text { Argentina }\end{array}$ & $\begin{array}{l}\text { Prospective } \\
\text { cohort study, }\end{array}$ & $\begin{array}{c}\text { BZN: } 5-8 \mathrm{mg} / \mathrm{kg} / \mathrm{day} \\
\text { (mean } 6.4 \\
\mathrm{mg} / \mathrm{kg} / \mathrm{day} \text { ) } \\
\text { bid ( } \mathrm{n}=76 \text { ) or tid ( } \mathrm{n}= \\
31 \text { ) } \\
\text { Mean length } 60 \text { days }\end{array}$ & $\begin{array}{l}107 \text { enrolled } \\
91 \text { completed }\end{array}$ & $\begin{array}{c}\text { After } 3 \text { year follow-up, PCR turned } \\
\text { negative on } 99 \% \text { of patients. } \\
\text { Out of } 66 \text { patients with initial } \\
\text { positive F2/3-ELISA that } \\
\text { completed: } 72.7 \% \text { became } \\
\text { negative. ( } 33.3 \% \text { at end of } \\
\text { treatment, } 13.3 \% \text { at } 6 \text { months, } \\
11.1 \% \text { at } 9 \text { months, } 8.9 \% \text { at } 26 \\
\text { months, } 20 \% \text { at } 36 \text { months and } \\
13.4 \% \text { at } 42 \text { months) }\end{array}$ & $\begin{array}{l}\text { Benznidazole was well tolerated } \\
\text { and ADRs were mild, not } \\
\text { requiring treatment suspension }\end{array}$ \\
\hline $\begin{array}{l}\text { Robello et al. } \\
2019 \\
153\end{array}$ & $\begin{array}{l}\text { IP* of CD 5-14 years } \\
\text { old } \\
\text { Bolivia }\end{array}$ & nical trial & $\begin{array}{l}\text { BZN: } 5 \mathrm{mg} / \mathrm{kg} \text { per } \\
\text { day for } 60 \text { days }\end{array}$ & $\begin{array}{l}55 \text { total }(20 \\
\text { enrolled/35 } \\
\text { completed) }\end{array}$ & \multicolumn{2}{|c|}{$\begin{array}{l}\text { Infected children had higher fecal Firmicutes (Streptococcus, } \\
\text { Roseburia, Butyrivibrio, and Blautia), and lower Bacteroides and also } \\
\text { showed some skin -but not oral- microbiota differences. Treatment } \\
\text { eliminated the fecal microbiota differences from control children, } \\
\text { increasing Dialister (class Clostridia) and members of the } \\
\text { Enterobacteriaceae, and decreasing Prevotella and Coprococcus, with } \\
\text { minor effects on the oral and skin bacterial diversity }\end{array}$} \\
\hline $\begin{array}{l}\text { Albareda et } \\
\text { al. } 2018 \\
47\end{array}$ & $\begin{array}{c}\text { IP* of CD 5-16 years } \\
\text { old } \\
\text { Argentina }\end{array}$ & Clinical trial & $\begin{array}{l}\text { BZN: } 5 \mathrm{mg} / \mathrm{kg} \text { per } \\
\text { day for } 60 \text { days NF: } \\
10 \mathrm{mg} / \mathrm{kg} \text { per day of } \\
\text { for } 60 \text { days } \\
\text { (drug source not } \\
\text { stated) }\end{array}$ & $\begin{array}{l}\text { Total } 52 \\
\text { BZN: } 45 \\
\text { NF: } 7\end{array}$ & $\begin{array}{l}\text { Treatment with BZN or NF } \\
\text { induced a decline in T. cruzi- } \\
\text { specific IFN-g- and IL-2 } \\
\text { Posttreatment changes in } \\
\text { several of these markers } \\
\text { distinguished children with a } \\
\text { declining serologic response } \\
\text { suggestive of successful } \\
\text { treatment from those with } \\
\text { sustained serological responses } \\
\text { in a 5-year follow-up study. }\end{array}$ & $\begin{array}{c}\text { Mild ADRs were observed in } 8 \text { out } \\
\text { of } 40(20 \%) \text { subjects under } \\
\text { treatment with BZN, while } 5 \\
\text { subjects }(12.5 \%) \text { showed severe } \\
\text { ADRs that resulted in treatment } \\
\text { suspension. } \\
\text { Cutaneous rash and dermatitis } \\
\text { were the main ADRs with BZN } \\
\text { treatment, whereas NF was well } \\
\text { tolerated. } \\
\text { The five children who received } \\
\text { incomplete BZN } \\
\text { dosing were then treated with NF }\end{array}$ \\
\hline
\end{tabular}




\begin{tabular}{|c|c|c|c|c|c|c|}
\hline $\begin{array}{l}\text { Altcheh et al. } \\
2014 \\
8\end{array}$ & $\begin{array}{l}\text { IP* of CD* } 2-12 \\
\text { years of age (mean } \\
7.3 \text { years) } \\
\text { Argentina } \\
55 \% \text { Male }\end{array}$ & $\begin{array}{c}\text { Prospective } \\
\text { population } \\
\text { pharmacokinetic } \\
\text { (PK) cohort }\end{array}$ & $\begin{array}{l}\text { BZN: } 5-8 \mathrm{mg} / \mathrm{kg} / \text { day } \\
\text { b.i.d. for } 60 \text { days } \\
\text { (mean dose }=6.4) \\
\left(\text { Radanil }{ }^{\circledR}\right)\end{array}$ & $\begin{array}{l}38 \text { enrolled } \\
37 \text { completed }\end{array}$ & $\begin{array}{l}\text { All patients had negative T. cruzi } \\
\text { PCR at Day } 60 \text { and at } 1.5 \text { year } \\
\text { follow-up with decreased } \\
\text { (compared to pre- treatment) T. } \\
\text { cruzi antibody titers. }\end{array}$ & $\begin{array}{l}\text { Four (10\%) patients had ADRs: } 1 \\
\text { mild rash, } 1 \text { moderate prurigo, } 1 \\
\text { generalized rash without systemic } \\
\text { involvement, and } 1 \text { moderate } \\
\text { eosinophilia. All ADRs subsided } \\
\text { with symptomatic treatment and } \\
\text { temporary drug discontinuation, } \\
\text { and all patients recovered } \\
\text { neventfully. }\end{array}$ \\
\hline $\begin{array}{c}\text { Rumi et al. } \\
2013 \\
154\end{array}$ & $\begin{array}{c}\text { IP* of CD* }<16 \text { years } \\
\text { of age (range } 3-15 \\
\text { years) Argentina }\end{array}$ & Clinical Trial & $\begin{array}{l}\text { BZN: } 5 \mathrm{mg} / \mathrm{kg} / \mathrm{day} \\
\text { b.i.d. for } 60 \text { days } \\
\text { (drug source not } \\
\text { stated, assumed } \\
\text { Roche product). }\end{array}$ & $\begin{array}{c}57 \text { treated } \\
45 \text { followed-up }\end{array}$ & $\begin{array}{l}\text { At 2-year follow-up (subset at 5- } \\
\text { year follow-up) almost no } \\
\text { patient demonstrated ELISA } \\
\text { seroconversion (however, } \\
\text { approximately half with reduced } \\
\text { titers) and almost all patients } \\
\text { was PCR negative. }\end{array}$ & $\begin{array}{l}\text { Safety reported from } 1 \text { of } 2 \text { sites } \\
\text { with } 32 \text { patients. ADRs in } 30 \% \text { of } \\
\text { patients. Dermatological, } \\
\text { gastrointestinal and neurological } \\
\text { most frequent. }\end{array}$ \\
\hline $\begin{array}{c}\text { Chippaux et } \\
\text { al. } 2013 \\
155\end{array}$ & $\begin{array}{c}\text { Newborn childr } \\
\text { with cCD } \\
\text { Bolivia }\end{array}$ & $\begin{array}{l}\text { Randomized, } \\
\text { placebo- } \\
\text { unblinded } \\
\text { controlled trial }\end{array}$ & $\begin{array}{l}\text { BZN: } 5 \mathrm{mg} / \mathrm{kg} / \mathrm{day} \\
\text { b.i.d. for } 60 \text { days } \\
\text { versus } 7.5 \\
\mathrm{mg} / \mathrm{kg} / \mathrm{day} \text { once } \\
\text { daily for } 30 \text { days } \\
\text { (Radanil }{ }^{\circledR} \text { ) } \\
\\
\text { Tablets ground up } \\
\text { and } 8,10,13 \text {, and } 15 \\
\text { mg of powder filled } \\
\text { into capsules. }\end{array}$ & $\begin{array}{c}63 \text { BZN } 5 \\
\mathrm{mg} / \mathrm{kg} / \text { day } 60 \\
\text { days } \\
\text { 61: BZN } 7.5 \\
\mathrm{mg} / \mathrm{kg} / \text { day } 30 \\
\text { days }\end{array}$ & $\begin{array}{l}\text { Microhematocrit method used } \\
\text { for diagnosis (all positive pre- } \\
\text { treatment) for } 1 \text { and } 2 \text { month } \\
\text { post-treatment follow-up (all } \\
\text { negative). } \\
\text { ELISA serology used at age 8-9 } \\
\text { months follow-up (all but } 1 \\
\text { patient negative). }\end{array}$ & $\begin{array}{c}5 \mathrm{mg} / \mathrm{kg} / \text { day: } 38 \% \text { of patients with } \\
\text { ADRs. Primarily gastrointestinal } \\
\text { and dermatological (5\%-10\% } \\
\text { frequency). } \\
7.5 \mathrm{mg} / \mathrm{kg} / \text { day: } 31 \% \text { of patients } \\
\text { with ADRs. Primarily } \\
\text { gastrointestinal and } \\
\text { dermatological ( } 5 \%-11 \% \\
\text { frequency) } \\
\text { Tolerability similar for both } \\
\text { treatment groups. Treatment } \\
\text { temporarily stopped for most } \\
\text { ADRs (<3 days) in both treatment } \\
\text { groups. }\end{array}$ \\
\hline
\end{tabular}




\begin{tabular}{|c|c|c|c|c|c|c|}
\hline $\begin{array}{l}\text { Altcheh et al. } \\
2011 \\
34\end{array}$ & $\begin{array}{c}\text { IP* of CD } 10 \text { days to } \\
19 \text { years of age } \\
\text { (median } 6.9 \text { years) } \\
\text { Argentina }\end{array}$ & $\begin{array}{l}\text { Prospective } \\
\text { cohort }\end{array}$ & $\begin{array}{l}\text { BZN: } 5-8 \mathrm{mg} / \mathrm{kg} / \mathrm{day} \\
\text { b.i.d. or t.i.d. for } 60 \\
\text { days (mean dose }= \\
\text { 6.4) }\left(\text { Radanil }{ }^{\circledR}\right) \\
\\
\text { Infant doses } \\
\text { provided as } \\
\text { fractioned tablets } \\
\text { administered in milk }\end{array}$ & $\begin{array}{l}107 \text { enrolled } \\
91 \text { completed }\end{array}$ & $\begin{array}{l}\text { Treatment response was high } \\
\text { and persistent, with over } 90 \% \text { of } \\
\text { children who completed } 60 \text { days } \\
\text { of treatment presenting a steady } \\
\text { decrease or disappearance of } \\
\text { specific } T \text {. cruzi antibodies and a } \\
\text { negative parasitological test (T. } \\
\text { cruzi-specific PCR and } \\
\text { microhematocrit). }\end{array}$ & $\begin{array}{c}\text { No serious ADRs. } 80.6 \% \text { mild, } 16 \% \\
\text { moderate, } 3.2 \% \text { severe } \\
\text { (generalized rash). } 7 \text { patients } \\
\text { (mostly older) discontinued due to } \\
\text { ADRs. } 41 \% \text { had ADRs related to } \\
\text { treatment: } \\
\text { Dermatological = } 21 \% \\
\text { CNS }=9 \% \\
\text { Gastrointestinal }=9 \% \\
\text { Neuromuscular }=3 \% \\
\text { Clinical }=71 \% \\
\text { Laboratory changes }=29 \% \\
\text { No difference in safety profile by } \\
\text { dosing regimen or gender, but } \\
\text { greater frequency in older } \\
\text { patients. }\end{array}$ \\
\hline $\begin{array}{l}\text { Chippaux et } \\
\text { al. } 2010 \\
42\end{array}$ & $\begin{array}{c}\text { Newborn children } \\
\text { with congenital CD } \\
* * * \text { Bolivia }\end{array}$ & Clinical trial & $\begin{array}{l}\text { BZN: } 2.5 \mathrm{mg} / \mathrm{kg} / \mathrm{day} \\
\text { b.i.d. for } 60 \text { days } \\
\text { (Group A) versus } 7.5 \\
\text { mg/kg/day once } \\
\text { daily for } 30 \text { days } \\
\text { (Group B) (Radanil }{ }^{\circledR} \text { ) } \\
\text { tablets ground up } \\
\text { and } 8,10,13 \text { and } 15 \\
\text { mg of powder filled } \\
\text { into capsules }\end{array}$ & $\begin{array}{l}257 \text { total } \\
\text { Group A: } 59 \\
\text { Group B: } 52 \\
\text { Two matched } \\
\text { controls for } \\
\text { each patient } \\
\text { enrolled (1 CD } \\
\text { negative } \\
\text { mother, } \\
\text { negative } \\
\text { newborn and } 1 \\
\text { CD positive } \\
\text { mother, } \\
\text { negative } \\
\text { newborn) }\end{array}$ & $\begin{array}{c}\text { Microhematocrit method used } \\
\text { for diagnosis with parallel ELISA } \\
\text { for following course of maternal } \\
\text { versus newborn } T \text {. cruzi } \\
\text { antibody titers. No significant } \\
\text { difference between BZN } \\
\text { treatment groups in time course } \\
\text { or degree of reduction in ELISA } \\
\text { titers. } \\
\text { Approximately } 90 \% \text { of treated } \\
\text { newborns had negative ELISA } \\
\text { serology by month } 10 .\end{array}$ & No safety results reported. \\
\hline
\end{tabular}




\begin{tabular}{|c|c|c|c|c|c|c|}
\hline $\begin{array}{c}\text { Escriba et al. } \\
2009 \\
156\end{array}$ & $\begin{array}{c}\text { IP* of } \mathrm{CD}<13 \text { years } \\
(28 \%<5 \text { years }) \\
\text { Honduras } \\
45 \% \text { male }\end{array}$ & Clinical trial & $\begin{array}{c}\text { BZN: } 7.5 \mathrm{mg} / \mathrm{kg} / \text { day } \\
\text { b.i.d. for } 60 \text { days } \\
\left(\text { Radanil }^{\circledR}\right)\end{array}$ & $\begin{array}{l}231 \text { enrolled } \\
229 \text { completed } \\
18 \text { month } \\
\text { follow-up } \\
27 \text { followed for } \\
\text { an additional } \\
1.5 \text { years. }\end{array}$ & $\begin{array}{l}\text { Serology decrease of } 75 \% \text { or } \\
\text { more compared to baseline at } \\
\text { 18-month follow up: } 88.2 \% \text { (13 } \\
\text { of } 27 \text { ) } \\
48.1 \% \text { that remained } \\
\text { seropositive at } 18 \text {-month follow- } \\
\text { up were seronegative at } 36- \\
\text { month follow-up. }\end{array}$ & $\begin{array}{l}\text { No serious ADRs. Most ADRs mild } \\
\text { or moderate. } 3 \text { patients } \\
\text { temporarily discontinued } \\
\text { treatment due to severe adverse } \\
\text { event (neurological). } \\
\text { Gastrointestinal }=27 \% \\
\text { Dermatological }=13 \% \\
\text { Neurological }=10 \% \\
\text { No difference in safety profile by } \\
\text { dosing regimen or gender, but } \\
\text { greater frequency in older } \\
\text { patients. }\end{array}$ \\
\hline $\begin{array}{l}\text { Yun et al. } \\
2009 \\
83\end{array}$ & $\begin{array}{c}\text { IP of CD }<18 \text { years of } \\
\text { age. } \\
\text { Honduras }=<12 \\
\text { years } \\
\text { Guatemala }=<15 \\
\text { years } \\
\text { Bolivia (rural) }=<15 \\
\text { years } \\
\text { Bolivia (peri-urban) } \\
=<18 \text { years }\end{array}$ & Clinical trial & $\begin{array}{c}\text { BZN: } 5-7.5 \\
\text { mg/kg/day b.i.d. or } \\
\text { t.i.d. for } 60 \text { days } \\
\text { (source of drug } \\
\text { product not stated } \\
\text { but given Roche } \\
\text { product was only } \\
\text { BZN available at the } \\
\text { time, this is } \\
\text { assumed). }\end{array}$ & $\begin{array}{c}\text { Total }=2,804 \\
\text { Honduras = } \\
231 \\
\text { Guatemala = } \\
124 \\
\text { Bolivia (rural) = } \\
1,409 \\
\text { Bolivia (peri- } \\
\text { urban) } \\
=1,040\end{array}$ & $\begin{array}{c}\text { Serology seroconversion to a } \\
\text { negative result at } 18 \text { months } \\
\text { post-treatment: } \\
\text { Honduras }=87.1 \% \\
\text { Guatemala }=58.1 \% \\
\text { Bolivia (rural) }=5.4 \% \\
\text { Bolivia (peri-urban) }=0 \%\end{array}$ & $\begin{array}{c}\text { Honduras: } \\
\text { ADRs = 50\% of patients; } 97 \% \text { mild, } \\
\text { 0\% moderate, } 3 \% \text { severe (latter all } \\
\text { neuromuscular-related). } \\
\text { Gastrointestinal }=27 \% \\
\text { Dermatological }=13 \% \\
\text { Neurological }=10 \% \\
\text { Guatemala: } \\
\text { ADRs = } 51 \% \text { of patients; } 81 \% \text { mild, } \\
14 \% \\
\text { moderate, } 5 \% \text { severe. } \\
\text { Dermatological }=26 \% \\
\text { Gastrointestinal }=25 \% \\
\text { Neuromuscular }=23 \% \\
\text { Other }=26 \%\end{array}$ \\
\hline $\begin{array}{c}\text { Chavez et al. } \\
2006 \\
157\end{array}$ & $\begin{array}{c}\text { IP* of CD 5-10 years } \\
\text { Bolivia }\end{array}$ & $\begin{array}{c}\text { Clinical field } \\
\text { (non-controlled) } \\
\text { trial }\end{array}$ & $\begin{array}{l}\text { BZN: } 8 \mathrm{mg} / \mathrm{kg} / \mathrm{day} \\
\text { for } 60 \text { days (drug } \\
\text { source not states, } \\
\text { assumed Roche } \\
\text { product) }\end{array}$ & 35 & $\begin{array}{c}\text { At 14-month follow-up 96\% } \\
\text { were still sero-positive on ELISA } \\
\text { ( } 75 \% \text { of patients showed a } \\
\text { decreased antibody titer of }>50 \% \\
\text { at } 12 \text {-month follow-up) and } 68 \% \\
\text { were positive on PCR }\end{array}$ & No safety results reported. \\
\hline
\end{tabular}




\begin{tabular}{|c|c|c|c|c|c|c|}
\hline $\begin{array}{l}\text { Streiger et al } \\
2004 \\
33\end{array}$ & $\begin{array}{c}\text { IP* of CD 1-14 years } \\
\text { Argentina }\end{array}$ & Controlled trial & $\begin{array}{l}\text { BZN: } 5 \mathrm{mg} / \mathrm{kg} / \mathrm{day} \\
\text { for } 30 \text { days b.i.d } \\
\mathrm{NF}: 12-15 \\
\mathrm{mg} / \mathrm{kg} / \text { day } 45-60 \\
\text { days b.i.d or t.i.d } \\
\text { (Source of drug } \\
\text { product not staten) }\end{array}$ & $\begin{array}{c}\text { Total: } 95 \\
\text { BZN: } 64 \\
\text { NF: } 7 \\
\text { No-treatment: } \\
24\end{array}$ & $\begin{array}{c}\text { Serology seroconversion to a } \\
\text { negative result at any point of } \\
\text { follow up: } \\
\text { NF: } 6 / 7(85,7 \%) \\
\text { BZN: } 23 / 37(62,2 \%) \\
\text { Untreated children did not } \\
\text { change the serology } \\
\\
75 \% \text { of treated children became } \\
\text { negative when treated at } \leq 4 \\
\text { years old and } 43 \% \text { when treated } \\
\text { at } \geq 9 \text { years old. }\end{array}$ & $\begin{array}{l}\text { NF: anorexia, weight-loss, hepatic } \\
\text { enlargement slighty painfully, mild } \\
\text { hepatic and renal toxicitiy (clinical } \\
\text { or laboratory findings) } \\
\text { BZN: vomiting, mild rash. } 2 \\
\text { patients (3.8\%) did not tolerate } \\
\text { BZN. }\end{array}$ \\
\hline $\begin{array}{l}\text { Schijman et } \\
\text { al. } 2003 \\
41\end{array}$ & $\begin{array}{l}\text { IP* of CD }<17 \text { years } \\
\text { divided by age of } \\
\text { initiation of therapy: } \\
\begin{array}{l}\text { - } 0-6 \text { months of } \\
\text { age } \\
7 \text { months-17 } \\
\text { years of age } \\
\text { Argentina }\end{array}\end{array}$ & Clinical trial & $\begin{array}{l}\mathrm{NF}\left(\text { Lampit }^{\circledR}\right) \\
\mathrm{mg} / \mathrm{kg} / \text { day } \text { or } \mathrm{BZN} \text { : } \\
\left.\text { (Radanil }^{\circledR}\right) \quad 5-8 \\
\mathrm{mg} / \mathrm{kg} / \text { day b.i.d. for } \\
60 \text { days }\end{array}$ & $\begin{array}{c}152 \text { enrolled } \\
40 \text { treated } \\
10<3 \text { months } \\
\text { of age } \\
6 \text { from } 7 \\
\text { months- } 2 \\
\text { years of age } \\
24>3 \text { years of } \\
\text { age }\end{array}$ & $\begin{array}{c}\text { Percentage of patients at } 2-3- \\
\text { year follow-up with } \\
\text { seroconversion (positive to } \\
\text { negative): } \\
<3 \text { months of age }=100 \% \\
7 \text { months- } 2 \text { years of age }=67 \% \\
>3 \text { years of age }=13 \%\end{array}$ & No safety results reported. \\
\hline $\begin{array}{l}\text { Galvao et al } \\
\qquad \begin{array}{l}2003 \\
35,158\end{array}\end{array}$ & $\begin{array}{c}\text { IP* of CD (range 7- } \\
12 \text { years) } \\
\text { Brazil (rural) }\end{array}$ & Clinical trial & $\begin{array}{c}\text { BZN: } 5-7 \mathrm{mg} / \mathrm{kg} / \text { day } \\
\text { b.i.d. for } 60 \text { days } \\
\text { versus placebo }\end{array}$ & $\begin{array}{c}127 \text { (64 BZN / } \\
65 \text { placebo) }\end{array}$ & $\begin{array}{c}\text { PCR was applied to a cohort of } T \text {. } \\
\text { cruzi-seropositive children who } \\
\text { had been exposed to BZN } \\
\text { chemotherapy or placebo } 3 \\
\text { years earlier } \\
\text { PCR at baseline: } 84.2 \% \text { positivity } \\
\text { Untreated patients had a 1.6- } \\
\text { fold-higher chance of remaining } \\
\text { PCR positive ( } 34 \text { of } 53 \text { versus } 23 \\
\text { of 58) than those who had } \\
\text { received BZN }\end{array}$ & No safety results reported. \\
\hline
\end{tabular}




\begin{tabular}{|c|c|c|c|c|c|c|}
\hline $\begin{array}{l}\text { Schenone F. } \\
\text { et al } 2003 \\
159\end{array}$ & $\begin{array}{l}\text { IP* of CD } \\
0-10 \text { years of age } \\
\text { Chile }\end{array}$ & Clinical trial & $\begin{array}{l}\mathrm{NF}\left(\text { Lampit }^{\oplus}\right): 10 \\
\mathrm{mg} / \mathrm{kg} / \text { day for }^{\circ} 30 \\
\text { days }\end{array}$ & 99 & $\begin{array}{c}\text { 100\% negative xenodiagnose, } \\
100 \% \text { negative PCR after } 3 \text { year } \\
\text { follow-up }\end{array}$ & $\begin{array}{l}95,3 \% \text { well tolerated. } 4,7 \% \text { mild } \\
\text { nauseas. None interrupted. }\end{array}$ \\
\hline $\begin{array}{l}\text { Solari et al. } \\
\quad 2001 \\
160\end{array}$ & $\begin{array}{l}\text { IP* of CD* } 0-10 \\
\text { years } \\
\text { Chile }\end{array}$ & Clinical trial & NF: Not shown & 66 & $\begin{array}{l}\text { 34/36 positive serology at } 36 \\
\text { months follow-up, } 100 \% \\
\text { negative xernodiagnose and PCR }\end{array}$ & No safety results reported. \\
\hline $\begin{array}{c}\text { Solari et al } \\
1998 \\
161\end{array}$ & $\begin{array}{l}\text { IP* of CD } \\
0-10 \text { years } \\
\text { Chile }\end{array}$ & Clinical trial & $\begin{array}{c}\mathrm{NF}: 7 \mathrm{mg} / \mathrm{kg} / \text { day } 60 \\
\text { days }\end{array}$ & 28 & $\begin{array}{c}100 \% \text { negative xenodiagnose, } \\
35.8 \% \text { negative PCR }\end{array}$ & No safety results reported. \\
\hline $\begin{array}{c}\text { Sosa-Estani et } \\
\text { al } 1998 \\
40\end{array}$ & $\begin{array}{c}\text { IP* of } C D \text { (range } \\
12 \text { years) } \\
\text { Argentina }\end{array}$ & $\begin{array}{l}\text { Randomized, } \\
\text { double-blind, } \\
\text { placebo- } \\
\text { controlled trial }\end{array}$ & $\begin{array}{l}\text { BZN: } 5 \mathrm{mg} / \mathrm{kg} / \mathrm{day} \\
\text { for } 60 \text { days } \\
\left(\text { Radanil }^{\circledR}\right)\end{array}$ & $\begin{array}{l}\text { Total: } 106 \\
55 \text { BZN / } 51 \\
\text { placebo }\end{array}$ & $\begin{array}{l}\text { Seroconversion to a negative } \\
\text { result after } 48 \text { months with } \\
\text { conventional serology: } \\
\text { BZN:11.3\% (5 of 44) } \\
\text { Placebo: } 4.5 \% \text { ( } 2 \text { of } 44 \text { ) } \\
\text { Seroconversion to a negative } \\
\text { result with F29 ElA increased } \\
\text { from } 35.7 \% \text { to } 62.1 \% \text { six and } 48 \\
\text { months, respectively, after } \\
\text { treatment. } \\
\text { No placebo-treated child } \\
\text { seroconverted to a negative } \\
\text { result by the end of follow-up }\end{array}$ & $\begin{array}{l}\text { Less than } 20 \% \text { of participants } \\
\text { reported ADRs that included } \\
\text { intestinal colic, cutaneous } \\
\text { maculopapular rush, headache, } \\
\text { anorexia, vomiting, nausea, } \\
\text { diarrhea, dizziness, paresthesia, } \\
\text { and light shivering of the hands. } \\
\text { During treatment only intestinal } \\
\text { colic and rush were more frequent } \\
\text { in the BZN group than in the } \\
\text { placebo group, appearing at days } \\
11.3 \text { and } 19.5 \text {, respectively. No } \\
\text { severe ADRs were reported. Six } \\
\text { (10\%) of } 55 \text { in the BZN group had } \\
\text { moderate ADRs. }\end{array}$ \\
\hline $\begin{array}{c}\text { De Andrade } \\
\text { et al } 1996 \\
35 \\
\text { De Andrade } \\
\text { et al } 2004 \\
113\end{array}$ & $\begin{array}{c}\text { IP* of CD (range 7- } \\
12 \text { years at } \\
\text { enrollement and 14- } \\
19 \text { years at end of } \\
\text { follow-up) } \\
\text { Brazil (rural) }\end{array}$ & $\begin{array}{l}\text { Randomized, } \\
\text { double-blind, } \\
\text { placebo- } \\
\text { controlled trial }\end{array}$ & $\begin{array}{l}\text { BZN: } 5-7 \mathrm{mg} / \mathrm{kg} / \text { day } \\
\text { b.i.d. for } 60 \text { days } \\
\text { versus placebo }\end{array}$ & $\begin{array}{l}130 \text { enrolled } \\
64 \text { BZN/65 } \\
\text { placebo }\end{array}$ & $\begin{array}{c}\begin{array}{c}\text { Seroconversion to a negative } \\
\text { result }\end{array} \\
\text { After } 3 \text { years follow up: } \\
\text { BZN: } 58 \% \text { ( } 37 \text { of } 64) \\
\text { Placebo: } 5 \% \text { ( } 3 \text { of } 65) \\
\text { Efficacy of BZN by intention to } \\
\text { treat: } 55.8 \% \\
\text { After } 6 \text { years follow up: } \\
\text { BZN: } 88.7 \% \text { ( } 47 \text { of } 53 \text { ), } \\
\text { Placebo: } 26.1 \% \text { ( } 12 \text { of } 46 \text { ) } \\
\text { Efficacy of BZN by intention to } \\
\text { treat: } 64.7 \%\end{array}$ & $\begin{array}{l}\text { Minor ADRs requiring no specific } \\
\text { medication were recorded in a } \\
\text { small proportion of individuals }\end{array}$ \\
\hline
\end{tabular}




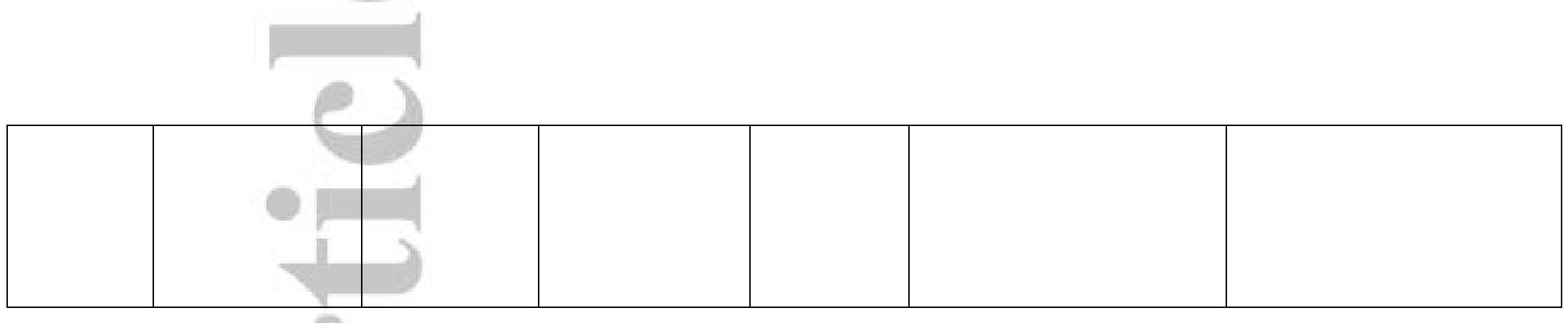

References Table 1:

*IP: Indeterminate phase 
Table 2: Candidate Chagas disease surrogate biomarkers. Modified from the book Chagas disease, a clinical approach, Freilij, H., Altcheh, J., (Chapter Chagas Disease Treatment Efficacy Biomarkers: Myths and Realities, Ruiz-Lancheros et al.)

\begin{tabular}{|c|c|c|c|}
\hline Biomarker type & Biomarker & Results in Chagas disease & References \\
\hline \multirow{3}{*}{ Parasite proteins } & Trypomastigotes F2/3 antigenic fraction & $\begin{array}{l}\text { Anti F2/3 decreases after BZN treatment and disappears } \\
\text { after } 4-21 \text { months in children }\end{array}$ & 120 \\
\hline & $\begin{array}{l}\text { Immunofluorescence assay of fixed } \\
\text { trypomastigotes (ISIFA) }\end{array}$ & $\begin{array}{c}\text { High titers in infected patients and low titers } 6 \text { years } \\
\text { after treatment when patients were considered cured. } \\
\text { High sensitivity and no cross-reactivity with other } \\
\text { diseases }\end{array}$ & 112,162 \\
\hline & $\begin{array}{l}\text { Trypomastigote mucin antigen A\&T CL- } \\
\text { ELISA }\end{array}$ & $\begin{array}{l}\text { Measure anti-Gal Abs. Titers decrease after BZN } \\
\text { treatment in adults and children }\end{array}$ & $113,163,164$ \\
\hline \multirow{7}{*}{$\begin{array}{l}\text { Parasite recombinant } \\
\text { proteins }\end{array}$} & $\begin{array}{l}\text { Ag13 } 85 \text { kDa protein with repeats of } 5 \\
\text { amino acids }\end{array}$ & $\begin{array}{c}\text { Anti-Ag13 is suitable for CD diagnosis in different } \\
\text { populations, and titers decrease and disappear after } 3 \\
\text { years posttreatment }\end{array}$ & 165 \\
\hline & T. cruzi ribosomal acid protein $\mathrm{P} 2 \beta$ & $\begin{array}{l}\text { Levels of Anti-P2 } \beta \text { decrease in asymptomatic treated CD } \\
\text { patients }\end{array}$ & 166 \\
\hline & $\begin{array}{l}\text { lant antigens KMP11, } \\
\text {, PFR2, Tgp63 }\end{array}$ & $\begin{array}{c}\text { A significant drop in reactivity against antigens between } \\
6 \text { and } 9 \text { months in BZN treated CD adults at different } \\
\text { stages of the disease. Titers continue to drop after } 24 \\
\text { months }\end{array}$ & 167,168 \\
\hline & 24 kDa calcium-binding protein (rTc24) & $\begin{array}{c}\text { Anti-rTC24 Abs decreases within 6-36 months post- } \\
\text { treatment }\end{array}$ & 169,170 \\
\hline & Flagellar calcium-binding protein (F29) & $\begin{array}{l}\text { Sero-reversion for the F29 antigen occurs between } 6 \text { and } \\
\quad 48 \text { months after BZN treatment in children }\end{array}$ & 40,119 \\
\hline & Multiplex 16 r T. cruzi proteins & $\begin{array}{c}\text { Decreased response of the panel } 36 \text { months after BZN } \\
\text { treatment in adults }\end{array}$ & 118,171 \\
\hline & $\begin{array}{l}\text { Recombinant complement regulatory } \\
\text { protein ( } \mathrm{rCRP})\end{array}$ & $\begin{array}{c}\text { Detect Abs complement-dependent as the CoML test. } \\
\text { Positive reactions decrease } 1-2 \text { years after BZN } \\
\text { treatment }\end{array}$ & 172 \\
\hline
\end{tabular}




\begin{tabular}{|c|c|c|c|}
\hline & $\begin{array}{l}\text { Putative microtubule-associated protein } \\
\text { (MAP) antigen3 }\end{array}$ & $\begin{array}{l}\text { Selected antigen from a multiplex array of } 15 \text { antigens } \\
\text { Results correlate with PCR-positive and PCR-negative } \\
\text { results in a cohort study } 5 \text { years after BZN treatment }\end{array}$ & 173 \\
\hline \multirow{3}{*}{$\begin{array}{l}\text { Host biochemical } \\
\text { markers }\end{array}$} & ApoA1 & $\begin{array}{c}\text { Downregulated in CD and normal levels after BZN or NFX } \\
\text { treatment }\end{array}$ & 174,175 \\
\hline & ApoA1 and FBN fragments & $\begin{array}{c}\text { Upregulated in CD and downregulated after BZN or NFX } \\
\text { treatments }\end{array}$ & 174,175 \\
\hline & $\begin{array}{l}\text { Lytic antibody complement-mediated } \\
\text { lysis (CoML) test }\end{array}$ & $\begin{array}{l}\text { Abs decreases until becoming negative after parasite } \\
\text { elimination in BZN and BFX treatments }\end{array}$ & 170 \\
\hline \multirow{3}{*}{$\begin{array}{l}\text { Host prothrombotic } \\
\text { markers }\end{array}$} & Prothrombin fragment $1+2(F 1+2)$ & $\begin{array}{l}\text { A marker of thrombin generation in vivo increases early } \\
\text { in } C D \text { and decreases after BZN treatment }\end{array}$ & 176,177 \\
\hline & Endogenous thrombin potential (ETP) & $\begin{array}{l}\text { Quantifies the ability to generate thrombin when } \\
\text { activated through tissue factor addition upregulated in } \\
\text { CD, decreases after BZN treatment }\end{array}$ & 176,177 \\
\hline & $\begin{array}{l}\text { Soluble platelet selectin } \\
\text { (sP-selectin) }\end{array}$ & $\begin{array}{l}\text { Biomarker of in vivo platelet activation decrease during } \\
\text { BZN therapy in adults and children }\end{array}$ & 177,178 \\
\hline \multirow{4}{*}{$\begin{array}{l}\text { Inmunological } \\
\text { markers }\end{array}$} & IFN- $\nu$ T cells & $\begin{array}{c}\text { Three-fold decrease compared with pretreatment } \\
\text { between } 1 \text { and } 3 \text { years posttreatment }\end{array}$ & 12 \\
\hline & CD3+ T cells & $\begin{array}{l}\text { CD3+ T-cell proportion differs between treated and } \\
\text { untreated patients and normalizes in cured patients }\end{array}$ & 179 \\
\hline & IL12+ CD14+ cells & $\begin{array}{l}\text { BZN-treated children show low levels of IL12+ CD14+ } \\
\text { cells and high levels of IL-10 modulated type } 1 \text { cytokines } \\
\text { profile }\end{array}$ & 180 \\
\hline & CD4+ LIR+ T cells & $\begin{array}{c}\text { Decrease of CD4+ LIR+ T cells after treatment between } 2 \\
\text { and } 6 \text { months and for at least } 2 \text { years }\end{array}$ & 47,181 \\
\hline
\end{tabular}

